\title{
Influence of intraseasonal eastern boundary circulation variability on hydrography and biogeochemistry off Peru
}

\author{
Jan Lüdke ${ }^{1}$, Marcus Dengler ${ }^{1}$, Stefan Sommer ${ }^{1}$, David Clemens $^{1}$, Sören Thomsen ${ }^{2}$, Gerd Krahmann ${ }^{1}$, \\ Andrew W. Dale ${ }^{1}$, Eric P. Achterberg ${ }^{1,3}$, and Martin Visbeck ${ }^{1,3}$ \\ ${ }^{1}$ GEOMAR Helmholtz Centre for Ocean Research Kiel, Düsternbrooker Weg 20, Kiel, Germany \\ ${ }^{2}$ LOCEAN-IPSL, IRD/CNRS/Sorbonnes Universites (UPMC)/MNHN, UMR 7159, Paris, France \\ ${ }^{3}$ Faculty of Mathematics and Natural Sciences, Christian-Albrechts-Universität zu Kiel, Kiel, Germany
}

Correspondence: Jan Lüdke (jluedke@geomar.de)

Received: 1 August 2019 - Discussion started: 5 August 2019

Revised: 6 July 2020 - Accepted: 20 August 2020 - Published: 9 November 2020

\begin{abstract}
The intraseasonal evolution of physical and biogeochemical properties during a coastal trapped wave event off central Peru is analysed using data from an extensive shipboard observational programme conducted between April and June 2017, and remote sensing data. The poleward velocities in the Peru-Chile Undercurrent were highly variable and strongly intensified to above $0.5 \mathrm{~m} \mathrm{~s}^{-1}$ between the middle and end of May. This intensification was likely caused by a first-baroclinic-mode downwelling coastal trapped wave, excited by a westerly wind anomaly at the Equator and originating at about $95^{\circ} \mathrm{W}$. Local winds along the South American coast did not impact the wave. Although there is general agreement between the observed cross-shoredepth velocity structure of the coastal trapped wave and the velocity structure of first vertical mode solution of a linear wave model, there are differences in the details of the two flow distributions. The enhanced poleward flow increased water mass advection from the equatorial current system to the study site. The resulting shorter alongshore transit times between the Equator and the coast off central Peru led to a strong increase in nitrate concentrations, less anoxic water, likely less fixed nitrogen loss to $\mathrm{N}_{2}$ and a decrease of the nitrogen deficit compared to the situation before the poleward flow intensification. This study highlights the role of changes in the alongshore advection due to coastal trapped waves for the nutrient budget and the cumulative strength of $\mathrm{N}$ cycling in the Peruvian oxygen minimum zone. Enhanced availability of nitrate may impact a range of pelagic and benthic elemental cycles, as it represents a major electron acceptor for
\end{abstract}

organic carbon degradation during denitrification and is involved in sulfide oxidation in sediments.

\section{Introduction}

The Peruvian upwelling system (PUS) is one of the most productive regions in the world's ocean with an economically important fishing industry (e.g. Carr, 2002; Chavez et al., 2008). Located in the eastern tropical South Pacific (ETSP), the high surface productivity of the PUS is most pronounced within a $100 \mathrm{~km}$ wide stretch along the Peruvian coast between 4 and $16^{\circ} \mathrm{S}$ (Pennington et al., 2006). Equatorward winds favour upwelling throughout the year (Bakun and Nelson, 1991; Strub et al., 1998) and enable a supply of nutrients from subsurface waters and benthic boundary layer to the euphotic zone, stimulating high primary productivity (Pennington et al., 2006). Below the surface layer, low-oxygen waters supplied to the PUS and enhanced local oxygen consumption due to remineralization of exported organic matter, leading to the development of a pronounced oxygen minimum zone (OMZ). The core of the OMZ with upper and lower bounds at about 30-200 and 400-500 m depth, respectively, is considered to be functionally anoxic (e.g. Ulloa et al., 2012; Thomsen et al., 2016).

The eastern boundary circulation in the PUS is dominated by the poleward Peru-Chile Undercurrent (PCUC) occupying the upper continental slope and shelf at depths from 50 to $200 \mathrm{~m}$ (Fig. 1, e.g. Gunther, 1936; Chaigneau et al., 2013). It carries low-oxygen and high-nutrient equatorial subsur- 
face water (ESSW), which constitutes the main source of the upwelled waters (Silva et al., 2009; Albert et al., 2010). Mean poleward velocities associated with the PCUC are between 0.05 and $0.15 \mathrm{~m} \mathrm{~s}^{-1}$ (Chaigneau et al., 2013). The origin of its source waters is still under debate. Chaigneau et al. (2013) traced its source waters to the Equatorial Undercurrent supplying the PCUC via the Ecuador-Peru Coastal Current, which flows poleward along the coast between the Equator and $5^{\circ} \mathrm{S}$. In contrast, a regional model analysis by Montes et al. (2010) suggests that the source waters of the PCUC originate predominately from the two eastward Southern Subsurface Countercurrents, flowing south of the Equator (Fig. 1). Above the PCUC, upwelling dynamics imply the existence of an equatorward geostrophic surface jet, known as the Peru Coastal Current (e.g. Hill et al., 1998; Kämpf and Chapman, 2016). Additional features of the eastern boundary circulation are the Peru-Chile Current flowing equatorward offshore of the PCUC and the Chile-Peru Deep Coastal Current flowing equatorward below the PCUC (Fig. 1, Strub et al., 1998; Chaigneau et al., 2013).

The PUS exhibits variability on a wide range of timescales, including intraseasonal (e.g. Gutiérrez et al., 2008; Illig et al., 2018a, b), seasonal (e.g. Pizarro et al., 2002) and interannual to decadal (e.g. Graco et al., 2017). Intraseasonal variability of oxygen and nutrient concentrations along the Peruvian margin are known to strongly impact pelagic and benthic ecosystems within the OMZ and the upwelling region above (e.g. Gutiérrez et al., 2008; Echevin et al., 2014; Graco et al., 2017). A prominent benthic example is the response of the biota to oxygenation or deoxygenation episodes with the dominant community changing from macro-invertebrates to bacterial mats (Thioploca/Beggiatoa) during prolonged anoxic episodes (Gutiérrez et al., 2008). Furthermore, in situations where nitrate is present in the anoxic OMZ, anaerobic degradation of organic matter via denitrification can still proceed, while a lack of nitrate favours benthic sulfide emissions, and toxic sulfide plumes in the water column may occur (Schunck et al., 2013; Dale et al., 2016).

A key factor thought to be responsible for the intraseasonal variability of oxygen and nutrient concentrations is the variability of the eastern boundary circulation, forced locally by changes of the wind system above the PUS or forced remotely by variability of the wind system at the Equator. Strengthening (weakening) of the local alongshore winds causes intensified (reduced) Ekman divergence close to the coast that accelerates (decelerates) the coastal surface jet (e.g. Philander and Yoon, 1982; Fennel et al., 2012). Coastal trapped waves (CTWs) are excited and propagate poleward to set up an alongshore pressure gradient balancing an accelerating (decelerating) alongshore flow (Yoon and Philander, 1982). Due to differences in the vertical structure of the surface jet and the excited CTWs, the poleward-flowing PCUC accelerates (decelerates). Furthermore, variability of local wind stress curl forces variability of the poleward un- dercurrent by affecting the magnitude of Sverdrup transport in the eastern boundary current regime (e.g. McCreary and Chao, 1985; Klenz et al., 2018).

Alternatively, variability of zonal winds in the equatorial Pacific forces equatorial Kelvin waves that propagate eastward. Upon reaching the continental margin, part of their incoming energy is transmitted poleward along the southwestern coast of South America as CTWs (e.g. Moore and Philander, 1977; Enfield et al., 1987). Early measurement programmes off Peru investigating intraseasonal alongshore current variability showed coherent CTW signals with periods of 5-50 d propagating poleward between 5 and $15^{\circ} \mathrm{S}$ (Brink et al., 1980, 1983; Romea and Smith, 1983). A lack of correlation between coastal tide gauge data and local winds suggested that the CTWs were predominately of equatorial origin. Similarly, intraseasonal CTW variability $(50 \mathrm{~d}$ period) in the PCUC off Chile with velocity amplitudes of up to $0.7 \mathrm{~m} \mathrm{~s}^{-1}$ were shown to have originated from wind variability in the central equatorial Pacific (Shaffer et al., 1997). Modelling efforts confirm that equatorially forced intraseasonal CTWs propagate along the eastern South American coast to as far as $30^{\circ} \mathrm{S}$ (Hormazabal et al., 2002; Illig et al., 2018b).

Poleward propagating CTWs produce vertical displacements of the pycnocline of the order of tens of metres and sea level changes of a few centimetres (Leth and Middleton, 2006; Belmadani et al., 2012). They also modulate the alongshore circulation; that is, CTWs that have a positive sea level anomaly and a downward displacement of the thermocline (downwelling waves) exhibit poleward flow, while CTWs that have a negative sea level anomaly (upwelling waves) exhibit equatorward flow (e.g. Echevin et al., 2014). The combined effect alters the horizontal and vertical supply of nutrients in the PUS. Modelling and satellite observations suggest that subsurface nutrient and chlorophyll intraseasonal variability in the PUS are mainly forced by remotely forced CTWs (Echevin et al., 2014). The simulations indicate that the shoaling and deepening of the nutricline, as well as the horizontal currents associated with the CTW, induce a nutrient flux in and out of the euphotic layer, which impacts primary production. On the other hand, intraseasonal sea surface temperature (SST) variability is suggested to be mainly driven by local winds and heat fluxes, with CTWs playing only a minor role (Dewitte et al., 2011; Illig et al., 2014).

Here, we use an extensive multi-parameter data set from a multi-cruise observational programme to analyse the impact of a strongly elevated and individual propagating CTW on the circulation, hydrography and nutrient concentrations in the PUS. By visiting sampling stations several times over a period of more than 2 months, we measured the variability of the circulation and hydrographic and biogeochemical conditions almost continuously and can distinguish the intraseasonal variability from processes taking place on shorter timescales. 


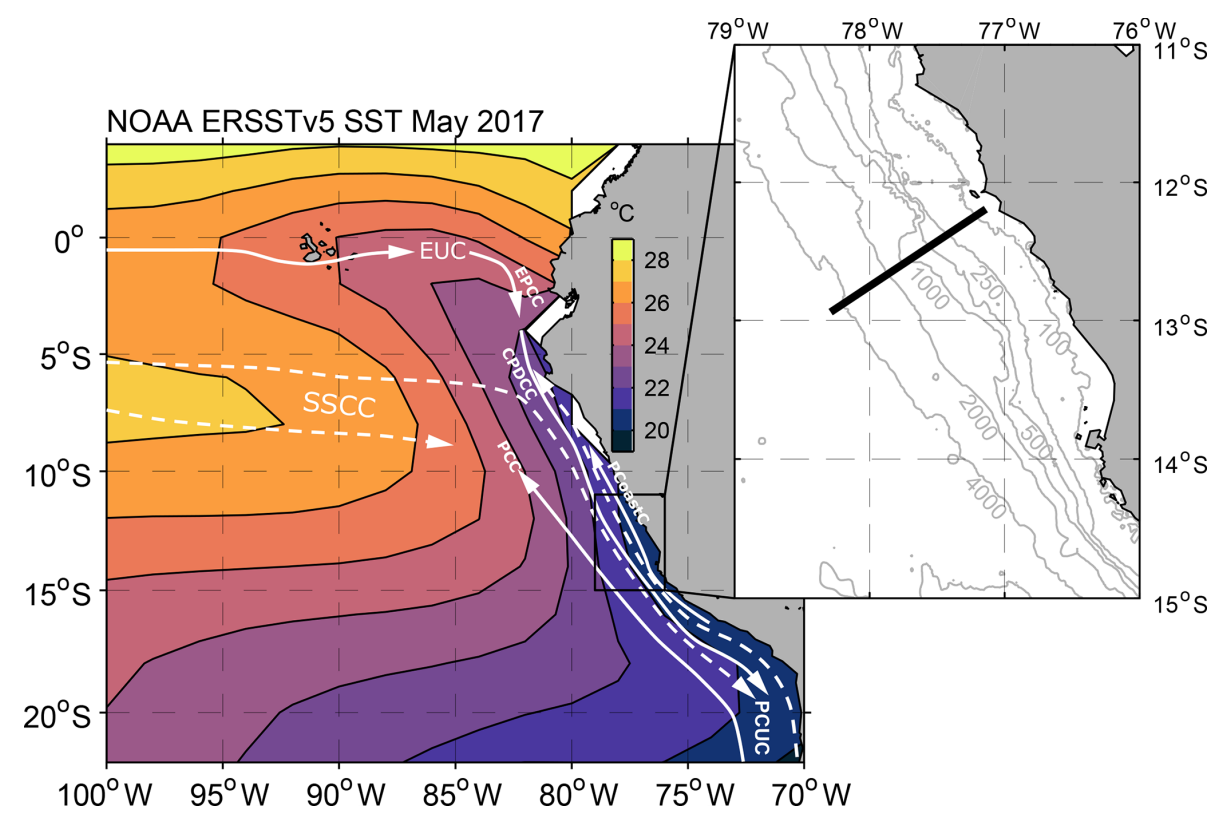

Figure 1. Sea surface temperature (NOAA ERSSTv5 SST) in the eastern tropical Pacific during May 2017 and schematic of the circulation. Solid white lines indicate surface layer currents, while dashed lines indicate thermocline layer currents (after Brandt et al., 2015). Abbreviated currents are the Equatorial Undercurrent (EUC), the Ecuador-Peru Coastal Current (EPCC), the Peru Coastal Current (PCoastC), the PeruChile Current (PCC), the two Southern Subsurface Countercurrents (SSCCs), the Chile-Peru Deep Coastal Current (CPDCC) and the PeruChile Undercurrent (PCUC). Figure insert shows the position of the $12^{\circ} \mathrm{S}$ section and local bathymetry (SRTM30 plus topography; Becker et al., 2009).

The conditions off Peru in early 2017 were further affected by anomalously warm temperatures in the upper ocean during March associated with a coastal El Niño event (e.g. Garreaud, 2018; Echevin et al., 2018). Our observations cover the declining phase of the coastal El Niño event in April and May when SST anomalies were decreasing.

\section{Data}

\subsection{Ship data}

Within the framework of the Collaborative Research Center 754 "Climate-Biogeochemistry Interactions in the Tropical Ocean", we carried out a combined physical and biogeochemical sampling programme in the ETSP from April to June 2017 during several legs on R/V Meteor (Table 1). A regional focus during the four individual cruises of the sampling programme was a transect starting at shallow waters off Callao (Peru) at about $12^{\circ} \mathrm{S}$ running offshore perpendicular to the coastline and ends at water depths greater than $5000 \mathrm{~m}$ and more than $100 \mathrm{~km}$ offshore (Fig. 1). During the first R/V Meteor cruise (M135), the $12^{\circ} \mathrm{S}$ section was studied towards the end of the cruise (7-8 April). The two subsequent cruises (M136 and M137) focused on benthic and pelagic work off Peru between 11 and $14^{\circ} \mathrm{S}$ (Dengler and Sommer, 2019; Sommer et al., 2019). Benthic lander measurements required the vessel to remain close to the section between 18 April and 29 May 2017, when repeated hydrographic and velocity measurements along the section were collected. The section was again sampled during the final cruise (M138; 24 June). In this study, we analyse shipboard velocity data and hydrographic profiles, as well as oxygen and nutrient concentration measurements from the repeated measurements along $12^{\circ} \mathrm{S}$.

\subsubsection{Shipboard velocity observations}

Upper-ocean velocities were recorded continuously using two vessel-mounted ocean surveyor acoustic Doppler current profiler (vmADCP) systems installed on R/V Meteor. One vmADCP was operated at a frequency of $75 \mathrm{kHz}$ (OS75) and its system configuration during the cruises varied only in depth bin settings. Depth bins of 4,8 or $16 \mathrm{~m}$ were chosen depending on strength of the backscatter signal and the focus of the investigation, allowing a maximum range of $750 \mathrm{~m}$. The second vmADCP operated at $38 \mathrm{kHz}$ (OS38) and recorded depth bins of $32 \mathrm{~m}$ while sampling an increased depth range $(30-1000 \mathrm{~m})$. During post-processing, vmADCP velocities were corrected using a mean amplitude and misalignment angle determined from water-track calibration (e.g. Fischer et al., 2003). Misalignment angles derived from individual ship accelerations and turns followed a Gaussian distribution having a standard deviation of less than $0.65^{\circ}$ for OS75 and less than $0.75^{\circ}$ for OS38 (Sommer et al., 2019). A temporal trend was not detectable. The uncertainty of the misalignment an- 
Table 1. Dates of R/V Meteor cruises conducted within the ETSP in 2017 including sampling time and number of conductivity-temperaturedepth (CTD) stations collected at $12^{\circ} \mathrm{S}$.

\begin{tabular}{llll}
\hline $\begin{array}{l}\text { R/V Meteor } \\
\text { cruise }\end{array}$ & Dates in 2017 & $\begin{array}{l}\text { Sampling duration } \\
\text { along } 12^{\circ} \mathrm{S}\end{array}$ & $\begin{array}{l}\text { CTD/nutrient } \\
\text { stations at } 12^{\circ} \mathrm{S}\end{array}$ \\
\hline M135 & 2 March-8 April & 2d & \\
M136 & 18 April-3 May & 15d & 59 profiles \\
M137 & 6-29 May & 23d & 92 profiles \\
M138 & 1 June-5 July & 1d & \\
\hline
\end{tabular}

gle calibration can be determined from its standard deviation divided by the square root of the number of independent estimates (e.g. Fischer et al., 2003). For our data, more than 100 independent estimates were available for each cruise, resulting in an angle uncertainty of less than $0.1^{\circ}$ and an associated velocity bias of less than $1 \mathrm{~cm} \mathrm{~s}^{-1}$ for underway data. Fischer et al. (2003) suggested an accuracy of $3 \mathrm{~cm} \mathrm{~s}^{-1}$ for hourly underway data recorded during calm conditions in the tropics.

\subsubsection{Hydrographic observations}

Along the $12^{\circ} \mathrm{S}$ section, a total of 151 hydrographic profiles were collected during cruises M136 and M137 with a lowered SeaBird SBE 9-plus conductivity-temperature-depth (CTD) system using double sensor packages for temperature, conductivity and oxygen. The CTD was attached to a General Oceanics rosette with 24 Niskin bottles of $10 \mathrm{~L}$ to collect water samples. For the calibration of the conductivity sensor, water samples were analysed with a Guildline Autosal Salinometer model $8400 \mathrm{~B}$. Correction coefficients for the CTD's conductivity sensors were derived using a multi-parameter fit of the Autosal conductivities against the uncalibrated CTD sensor measurements.

CTD oxygen sensors were calibrated against oxygen concentrations determined from bottle water samples using Winkler titration (Winkler, 1888; Grasshoff et al., 1983). Processing and calibration followed the GO-SHIP recommendations (Hood et al., 2010). Previous studies using switchable trace amount oxygen (STOX) sensors have shown that the core of the Peruvian OMZ is functionally anoxic (Revsbech et al., 2009; Thomsen et al., 2016). Unfortunately, the Winkler titration method fails to accurately determine very low oxygen concentrations from bottle water samples. To assure anoxic conditions in the OMZ core, a mean oxygen concentration offset of $2.26 \mu \mathrm{mol} \mathrm{L}^{-1}$ was subtracted from low oxygen values. Calibration of the salinity and oxygen sensors was performed separately for each cruise, except for M136 where the mean of the calibration of the preceding and succeeding cruises (M135 and M137) was used (M136 lacked deep-water samples required for calibration purposes). The final post-cruise calibration of the data resulted in an accuracy for temperature, salinity and oxygen of $0.002^{\circ} \mathrm{C}$, $0.002 \mathrm{~g} \mathrm{~kg}^{-1}$ and $1.5 \mu \mathrm{mol} \mathrm{kg}-1$, respectively.

\subsubsection{Nutrient measurements}

Water samples collected during the upcast of the CTD rosette were used to determine nutrient concentrations. Concentrations of nitrate, nitrite and phosphate were measured using a QuAAtro autoanalyser (Seal Analytical) with a precision of $0.1,0.1$ and $0.2 \mu \mathrm{mol} \mathrm{L}^{-1}$, respectively (Sommer et al., 2019). Ammonium concentrations were measured using a fluorimetric method (Holmes et al., 1999).

In addition, concentrations of nitrate were measured using a Satlantic deep Submersible Ultraviolet Nitrate Analyzer (SUNA) mounted on the CTD rosette (Hauschildt et al., 2020). SUNA measurements are based on the absorbance spectra of ultraviolet light (Sakamoto et al., 2009). Data postprocessing followed Karstensen et al. (2017) and Thomsen et al. (2019). In a final step, the SUNA nitrate concentrations were calibrated against the nitrate concentrations from the CTD water samples using a linear fit.

\subsection{Additional data}

Additional regional data sets from satellite observations were used to supplement our analysis of shipboard observations. Sea level anomaly (SLA) data based on satellite altimeter measurements were provided by the EU Copernicus Marine Environmental Monitoring Service (product: SEALEVEL_GLO_PHY_L4_REP_OBSERVATIONS_008 _047). This is a level-4 data set derived by merging all available satellite altimetry data into one gridded product. Reprocessed data from 1 January 1993 to 1 January 2018 with the release days 15 January 2018 (data before 15 May 2017) and 16 May 2018 were accessed. Additionally, sea surface temperature from the NOAA Extended Reconstructed Sea Surface Temperature version 5 (ERSSTv5) data set (Huang et al., 2017a) was analysed. This data set provides monthly values of SST on a $2^{\circ} \times 2^{\circ}$ grid based on in situ temperature observations from several sources (Huang et al., 2017b). Finally, wind stress data from the Advanced Scatterometer (ASCAT) product of satellite scatterometer winds (Bentamy and Fillon, 2012) were analysed. This product provides daily global winds and wind stress data with a resolution of $0.25^{\circ}$. 


\section{Methods}

\subsection{Analysis of velocity observations}

The continuous velocity recording was split into segments when the ship was moving in on- or offshore directions only. The velocities were rotated to derive the alongshore component and then a mean velocity section was calculated for each segment of the cruise in $2 \mathrm{~km}$ bins according to offshore distance. Periods where the ship was moving slower than $1 \mathrm{kn}$ were excluded. To derive the sections of alongshore velocity over longer time periods, the data from several of these segments were averaged. The presented sections were smoothed using a 2-D Gaussian weights.

\subsection{Analysis of hydrographic and biogeochemical data}

The analysis of hydrographic data was based on the TEOS10 definitions. Conservative temperature, absolute salinity, density and potential density anomalies were calculated with the Matlab Gibbs Seawater Toolbox (version 3.05; McDougall and Barker, 2011). Nutrient concentrations were transformed to $\mu \mathrm{mol} \mathrm{kg} \mathrm{g}^{-1}$ to remove the effect of compressibility on vertical gradients. In the following, we use "temperature" to refer to conservative temperature and use "salinity" to refer to absolute salinity.

\subsubsection{Nitrogen deficit}

In suboxic environments, microbially mediated processes such as denitrification and anaerobic ammonium oxidation (anammox) transform biologically available reactive nitrogen (nitrate, nitrite and ammonium) via intermediate steps into dinitrogen $\left(\mathrm{N}_{2}\right)$, which cannot be used by most organisms. These processes lead to a loss of reactive nitrogen relative to other nutrients such as phosphate $\left(\mathrm{PO}_{4}^{3-}\right)$. The global distribution of nitrate, phosphate and dissolved inorganic carbon (DIC) displays a strong covariation, with the slope of $\mathrm{N}: \mathrm{P}$ of about $16: 1$ reflecting the mean stoichiometry of organic matter synthesis and degradation. In order to analyse the impact of nitrogen loss and $\mathrm{N}_{2}$ fixation on the $\mathrm{NO}_{3}^{-}$distribution, it is convenient to remove the photosynthesis/remineralization trend and only focus on deviations, $N_{\text {def }}$, from this trend. The concept of $N_{\text {def }}$ has been introduced (Gruber and Sarmiento, 1997, 2002). Here, the formulation of Chang et al. (2010) was applied to investigate $N_{\text {def }}$ $\left(\mu \mathrm{mol} \mathrm{kg}{ }^{-1}\right)$. It is based on the deviation from the ratio between nitrogen species and phosphate outside of the eastern tropical South Pacific OMZ and is calculated as

$N_{\text {def }}=15.8\left(\mathrm{PO}_{4}^{3-}-0.3\right)-\left(\mathrm{NO}_{3}^{-}+\mathrm{NO}_{2}^{-}+\mathrm{NH}_{4}^{+}\right)$,

where $\mathrm{PO}_{4}^{3-}, \mathrm{NO}_{3}^{-}, \mathrm{NO}_{2}^{-}$and $\mathrm{NH}_{4}^{+}$are the concentrations of phosphate, nitrate, nitrite and ammonium, respectively. With this definition, positive values of $N_{\text {def }}$ quantify an $\mathrm{N}$ loss that has occurred within a certain water mass while it remained in the Peruvian OMZ.

\subsubsection{Section averaging}

Smoothed hydrographic and biogeochemical properties along the $12^{\circ} \mathrm{S}$ section were calculated by interpolating the data vertically onto common potential density surfaces. Averaging in density space removes the effect of signal smearing due to vertical displacement caused by internal waves. The profiles were then averaged in bins of $2 \mathrm{~km}$ according to distance from the coastline and then smoothed using 2-D Gaussian weights. In a final step, the averaged and smoothed sections were vertically transformed back into depth space using the smoothed depth-density relation.

\subsection{Sea level anomaly and wind data}

The local SLA along the $12^{\circ} \mathrm{S}$ section was calculated by first averaging all daily gridded SLA data between 12 and $12.5^{\circ} \mathrm{S}$ over the time periods used for the velocity sections and interpolating them onto the section according to the distance to the coast. Grid points closer than $30 \mathrm{~km}$ to the coast were excluded. Then the mean SLA along the section was subtracted to focus on the cross-shore gradient. In addition, intraseasonal variability along the Equator and coastline was analysed by subtracting the mean SLA over the 25-year time series before bandpass filtering SLA using a fourth-order Butterworth filter for a time window between 20 and $90 \mathrm{~d}$. To follow intraseasonal SLA variability due to propagating waves along the Equator and subsequently along the western South American coast, we used bandpass-filtered SLA data averaged between $0.25^{\circ} \mathrm{S}$ and $0.25^{\circ} \mathrm{N}$ from the Equator and two-grid-point averages from near the coast.

For investigating wind forcing of Kelvin waves at the Equator, SLA and zonal wind anomaly were averaged to $5 \mathrm{~d}$ means over $10^{\circ}$ of longitude. Additionally, wind anomaly was averaged between $5^{\circ} \mathrm{N}$ and $5^{\circ} \mathrm{S}$, while SLA was averaged between $2^{\circ} \mathrm{N}$ and $2^{\circ} \mathrm{S}$.

\subsection{Theoretical coastal trapped wave structure}

To interpret the observed flow variability along the Peruvian coast in terms of CTWs, the cross-shore-depth structure of CTWs was determined by considering the linear, hydrostatic, inviscid and Boussinesq approximated equations of motion on an $f$ plane using local bathymetry and stratification (Brink, 1982, 1989; Illig et al., 2018a). For alongshore scales larger than cross-shore scales and horizontally uniform stratification, cross-shore-vertical mode structures (eigenfunctions) and corresponding phase velocity (eigenvalue) solutions were obtained from the simplified set of equations by using a resonance iteration approach (Brink, 1982; Brink and Chapman, 1987). Here, we obtained the eigenfunctions and eigenvalues for the first three modes by applying a modified version of the Brink and Chapman (1987) CTW programmes as published by Brink (2018). 
Local bathymetry and stratification are required as input to Brink's (2018) set of Matlab mfiles. The cross-shore distribution of bathymetry was taken from the multi-beam echo sounder data collected during the cruises along $12^{\circ} \mathrm{S}$. Echo sounder data were averaged in $5 \mathrm{~km}$ bins which resulted in a monotonic increase of water depth in the offshore direction. The maximum water depth used for the wave solutions was $5000 \mathrm{~m}$. From two offshore CTD profiles (M136 no. 60 and M137 no. 92) exceeding $3000 \mathrm{~m}$ depth, a stratification profile was calculated first for each profile using 20 data points with $1 \mathrm{dbar}$ spacing, and then a mean profile was calculated from both casts in $5 \mathrm{~m}$ intervals.

\section{Results}

\subsection{Variability of the boundary circulation}

The direct velocity observations from the multi-cruise programme allowed a detailed assessment of the variability of the eastern boundary alongshore velocity structure at $12^{\circ} \mathrm{S}$ for a period of more than 11 weeks (Fig. 2). During the observational period from early April to 24 June (2017), we captured an event of strongly increased poleward flow that started in early May and lasted for about $35 \mathrm{~d}$.

The time series started with $2 \mathrm{~d}$ of sampling from 7 to 8 April. During this period, a distinct poleward-flowing PCUC was present that extended $80 \mathrm{~km}$ offshore (Fig. 2a) and had maximum velocities of more than $0.3 \mathrm{~m} \mathrm{~s}^{-1}$ on the continental shelf. Satellite altimetry indicated an increasing SLA towards the coast (Fig. 2a). Between 18 April and 26 May, and except for a short break from 4 to 6 May, the $12^{\circ} \mathrm{S}$ section was continuously surveyed. In mid-April, a poleward flow was present only on the shelf (Fig. 2b). However, from the end of April to mid-May, the PCUC considerably strengthened, reaching maximum core velocities of about $0.5 \mathrm{~m} \mathrm{~s}^{-1}$ between 50 and $100 \mathrm{~m}$ depth $50 \mathrm{~km}$ offshore (Fig. 2c-e). Furthermore, the PCUC poleward flow extended to more than $80 \mathrm{~km}$ offshore and occupied the water column above $400 \mathrm{~m}$ depth. The SLA increased towards the coast (by $2 \mathrm{~cm}$ over $40 \mathrm{~km}$ ), implying that a poleward geostrophic velocity anomaly was present at the sea surface as well. Towards the end of May, poleward flow in the PCUC did not increase further but remained at a similar level as during mid-May (Fig. 2f). In contrast, velocity data from a final section occupation 3 weeks later on 24 June show evidence that the PCUC had weakened drastically (Fig. 2g), exhibiting a comparable velocity distribution as for the period 18-25 April (Fig. 2b). Assuming similar timescales for its deceleration as for its acceleration, the period of intensified PCUC flow was between 30 to $40 \mathrm{~d}$. The intensified PCUC flow strongly exceeded the climatological PCUC flow reported from this region. Mean alongshore flow at $12^{\circ} \mathrm{S}$ determined from vmADCP data sampled during 22 cruises showed maximum PCUC core velocities of $0.1-0.15 \mathrm{~m} \mathrm{~s}^{-1}$
(Chaigneau et al., 2013), similar to the situation observed during 18-25 April and 24 June (Fig. 2b and g).

In April, the velocity sections indicated an equatorward flow offshore and below the PCUC (Fig. 2). The Peru Coastal Current and the Chile-Peru Deep Coastal Current are thought to be located at these depths and offshore ranges (e.g. Penven et al., 2005; Chaigneau et al., 2013). In late April, the equatorward flow increased in strength and extended to shallower depths (Fig. $2 \mathrm{~b}$ and c). However, during the period of strong poleward flow in May, the equatorward flow decreased and was present only below $400 \mathrm{~m}$ depth close to the offshore end of the section (Fig. 2e and f). On 24 June, a weak equatorward flow was present below $200 \mathrm{~m}$ at most parts of the section but never reached velocities of $0.1 \mathrm{~m} \mathrm{~s}^{-1}$. We found no indication of equatorward flow above or inshore of the PCUC, where the equatorward surface jet is expected to be situated. The lack of this surface flow in observations was also noted by Chaigneau et al. (2013).

To compare the alongshore circulation with hydrographic and biogeochemical sampling, the data were averaged into two periods: the initial phase of weak poleward flow (Fig. 3a) covering the period of 18 April-3 May and a period of enhanced poleward flow during 12-26 May (Fig. 3b). The increase in poleward velocities was especially strong between 40 and $60 \mathrm{~km}$ offshore where velocities increased from about zero to $0.4 \mathrm{~m} \mathrm{~s}^{-1}$ (Fig. 3c). The core of velocity increase extended deeper than the intensified PCUC and was more detached from the coast.

\subsection{Potential causes of circulation variability}

\subsubsection{Role of local wind stress}

Changes in the local wind stress curl are a potential local forcing mechanism of an intensified PCUC flow. An increase in the magnitude of near-coastal negative wind stress curl leads to an increased poleward flow along the eastern boundary through Sverdrup dynamics (e.g. Marchesiello et al., 2003). The adjustment of the circulation to changes in the wind stress curl at the eastern boundary is rather fast and occurs within a few days (Klenz et al., 2018). Wind stress curl along the Peruvian continental margin between 10 and $14^{\circ} \mathrm{S}$ was negative throughout the observational period (Fig. 4), continuously forcing poleward flow. However, during the period of PCUC acceleration between the end of April and mid-May, the magnitude of negative wind stress curl decreased (Fig. 4c-f). It can thus be ruled out that local wind stress curl forcing is responsible for the observed intensified PCUC. Nevertheless, elevated negative wind stress curl was observed from 18 to 22 May, which may have contributed to maintain a strong PCUC in late May.

Variability of near-coastal alongshore wind stress excites CTWs that propagate poleward (e.g. Yoon and Philander, 1982) and thereby enhances or decreases poleward flow within the depth range of the PCUC. From mid-April to 


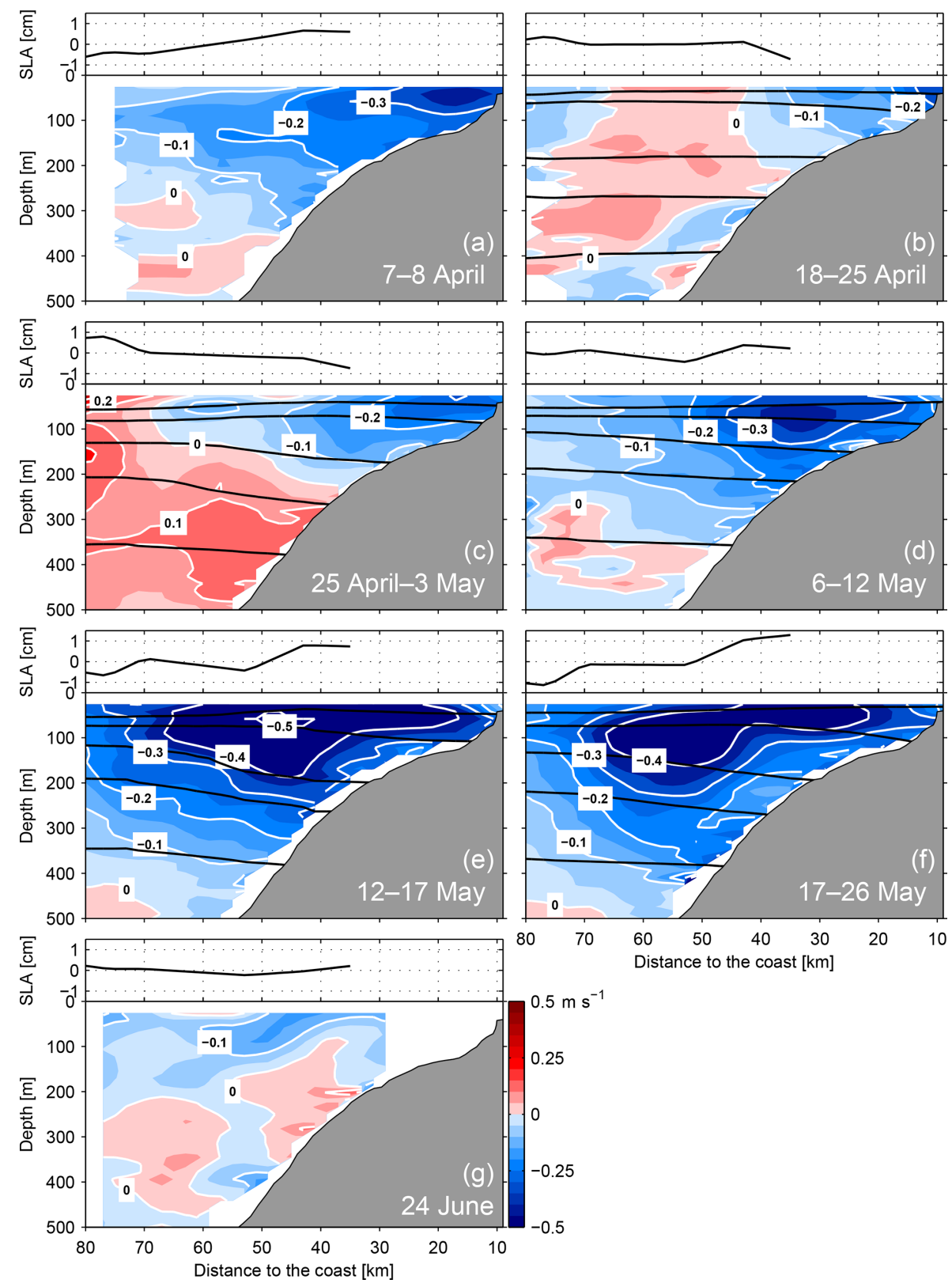

Figure 2. Depth-distance distribution of alongshore velocity (in $\mathrm{m} \mathrm{s}^{-1}$, positive equatorward, coloured contour plots) and sea level anomaly (in cm, black line in panel above contour plots) at $12^{\circ} \mathrm{S}$ during 7-8 April (a), 18-25 April (b), 25 April-3 May (c), 6-12 May (d), 12-17 May (e), 17-26 May (f) and 24 June 2017 (g). Black lines indicate the distribution of isopycnals $\left(\sigma_{\theta}\right)$ at $25.6,25.9,26.2,26.4$ and $26.7 \mathrm{~kg} \mathrm{~m}{ }^{-3}$.

May 2017, alongshore wind stress between 6 and $15^{\circ} \mathrm{S}$ was variable (Fig. 5). While moderate wind stress (0.03$0.06 \mathrm{~N} \mathrm{~m}^{-2}$ ) prevailed from mid-April to 3 May, it was weak during the first 2 weeks of May (Fig. 5d, e, g). On 15 May, the wind stress increased and remained elevated for a period of about $5 \mathrm{~d}$. This wind variability cannot explain the observed changes in poleward transport. The poleward transport increased from late April to its maximum mid-May, whereas the alongshore wind stress during this period decreased in the first week and then increased $7 \mathrm{~d}$ later.

\subsubsection{Equatorial winds and wave response}

According to equatorial linear wave theory a weakening of the trade winds at the Equator by, e.g. westerly wind events, generates an eastward propagating equatorial Kelvin wave. Once the equatorial Kelvin wave interacts with the eastern boundary, parts of its energy are transmitted to a CTW (Enfield et al., 1987). Indeed, several westerly wind anomalies occurred in the central and eastern equatorial Pacific during the first 6 months of 2017 (Fig. 6). A particularly ele- 

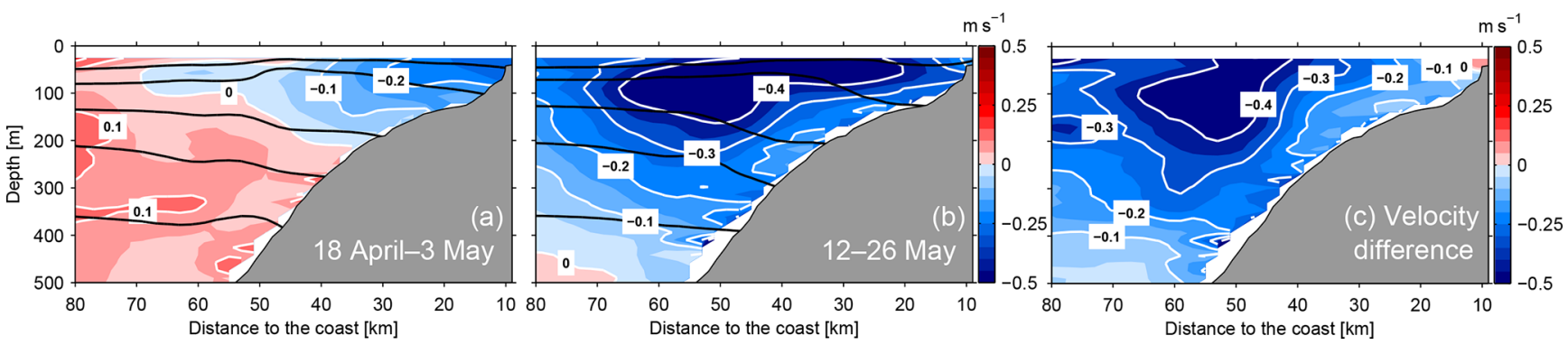

Figure 3. Depth-distance distribution of averaged alongshore velocity (positive equatorward) at $12^{\circ} \mathrm{S}$ prior to (a, 18 April-3 May 2017 ) and during (b, 12-26 May 2017) the PCUC intensification period. Panel (c) depicts the velocity difference between the two situations. Black lines indicate the distribution of isopycnals $\left(\sigma_{\theta}\right)$ at $25.6,25.9,26.2,26.4$ and $26.7 \mathrm{~kg} \mathrm{~m}^{-3}$.

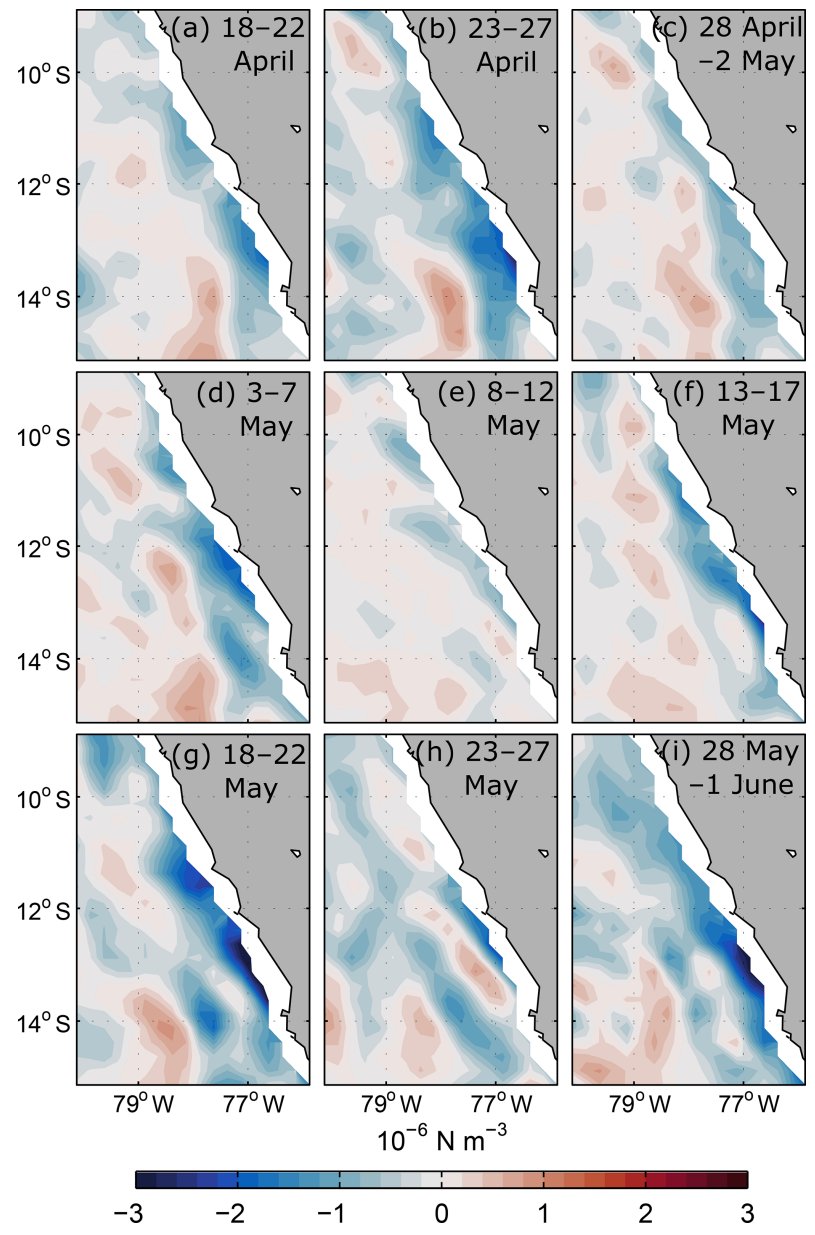

Figure 4. The $5 \mathrm{~d}$ mean wind stress curl from ASCAT scatterometer winds off Peru during 18-22 April (a), 23-27 April (b), 28 April2 May (c), 3-7 May (d), 8-12 May (e), 13-17 May (f), 18-22 May (g), 23-27 May (h) and 28 May-1 June 2017 (i).

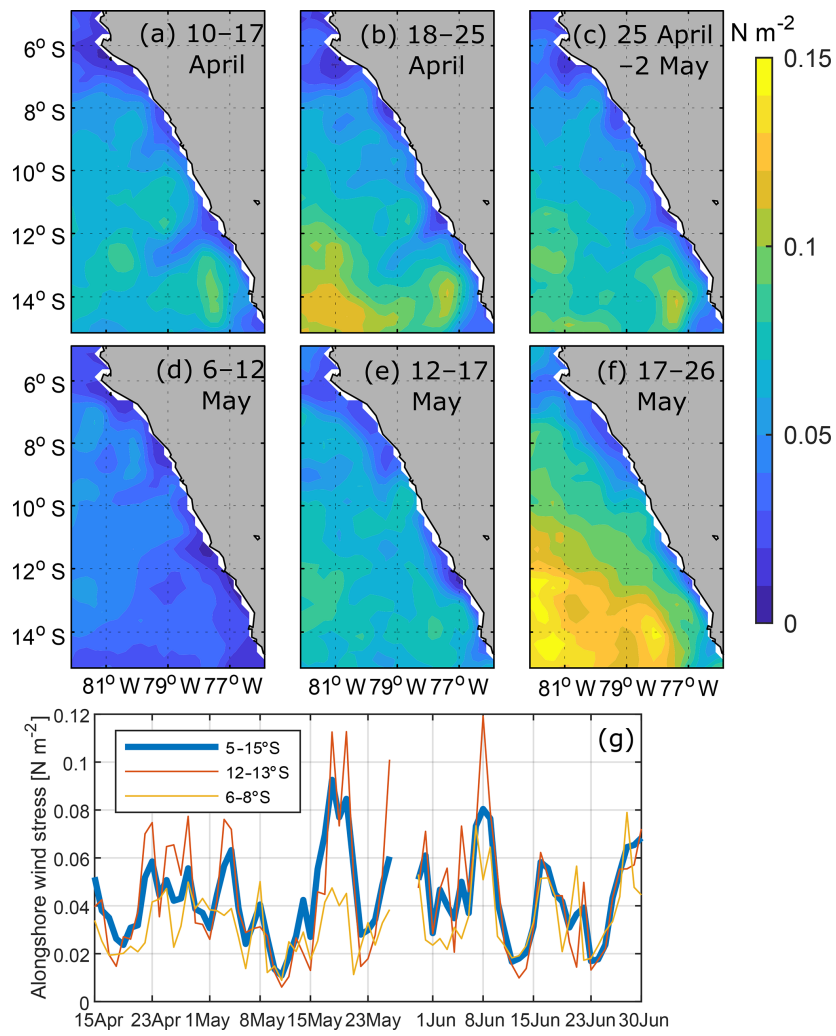

Figure 5. Alongshore wind stress from ASCAT scatterometer winds (a-f) averaged over 10-17 April (a), 18-25 April (b), 25 April2 May (c), 6-12 May (d), 12-17 May (e) and 17-26 May (f). Panel (g) shows time series of alongshore wind stress averaged between 30 and $80 \mathrm{~km}$ from the coast for different bands of latitude. 


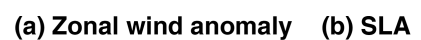

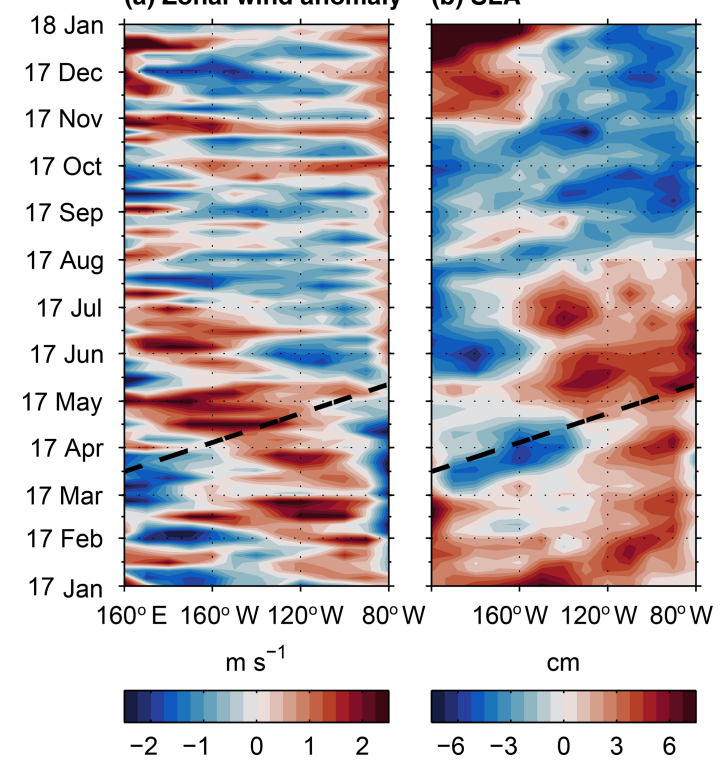

Figure 6. Hovmöller diagram of zonal wind anomaly (a) and SLA (b) along the central and eastern equatorial Pacific for the year 2017. The propagation of a first-mode equatorial Kelvin wave is indicated by the dashed black line (phase speed $2.7 \mathrm{~m} \mathrm{~s}^{-1}$; Yu and McPhaden, 1999).

vated westerly wind anomaly occurred between the International Date Line and $120^{\circ} \mathrm{W}$ during the first 2 weeks of April (Fig. 6a). In response, a positive SLA propagating along the Equator appeared to the east of the wind event between about 100 and $80^{\circ} \mathrm{W}$ (Fig. 6b, dash line, Fig. 7) and arrived at the eastern boundary at the beginning of May.

Bandpass-filtered SLA data from the Equator and from near the continental slope (Sect. 3.3) along the South American continent (Fig. 7) indicate that the positive SLA arriving at the eastern boundary continued southward along the eastern boundary to about $14^{\circ} \mathrm{S}$. Along the Equator, the propagation speed of the SLA was about $2.7 \mathrm{~m} \mathrm{~s}^{-1}$ (dashed line in Fig. 7a), which agrees with the phase speed of a first vertical mode equatorial Kelvin wave (e.g. Yu and McPhaden, 1999). The speed of propagation of the SLA signal along the eastern boundary was somewhat enhanced and around $3 \mathrm{~m} \mathrm{~s}^{-1}$. A positive SLA signal was associated with a negative (downward) displacement of the thermocline, eastward upper-ocean velocities at the Equator and poleward upperocean velocities at the continental slope. This agrees well with the SLA signal and the increased poleward PCUC velocities at $12^{\circ} \mathrm{S}$ and suggests the existence of a downwelling CTW during May 2017.

\subsubsection{Modal structure of the intensified flow}

To further investigate the nature of the boundary flow intensification, the cross-shore-depth structure of alongshore velocity was determined for the first three CTW modes at $12^{\circ} \mathrm{S}$
(Fig. 8; see Sect. 3.4 for a description of the model used). Due to a steep continental slope at $12^{\circ} \mathrm{S}$, the velocity structure of the different CTW solutions varied predominately in the vertical axis with poles of opposing velocity located above each other (Fig. 8). Flow reversal for each individual mode away from the boundary occurs at shallower depth compared to inshore regions. Higher modes exhibit an upper pole of enhanced velocity located at shallower depth compared to lower modes.

For comparison, Fig. 8e shows the difference of full-depth low-frequency vmADCP alongshore velocities between 1226 May and 18 April-3 May. Apart from the increased poleward velocity in the upper $500 \mathrm{~m}$, the alongshore velocity difference resolved by OS38 was weakly poleward throughout the upper $1000 \mathrm{~m}$ of the water column (Fig. 8e). Comparing the baroclinic structure of the observations to the baroclinic structure of the different CTW modes, the missing flow reversal in the upper $1000 \mathrm{~m}$ shows that the observed change in alongshore velocity is best described by a firstmode CTW. This mode features poleward flow anomalies throughout the upper $1500 \mathrm{~m}$ (Fig. 8b) which agrees with the distribution of the velocity differences between the two time periods throughout most of the upper $1000 \mathrm{~m}$ (Fig. 8e). The maximum increase of poleward flow, on the other hand, was restricted to a depth range similar to the upper poleward velocity core of a second-mode CTW.

Additional support for the presence of a first-mode CTW originates from a comparison of the phase speeds. At $12^{\circ} \mathrm{S}$, the local phase speeds of the model CTW modes (Fig. 8) were higher than those for equatorial Kelvin waves. In particular, the phase speed of the first-mode CTW was $3.1 \mathrm{~m} \mathrm{~s}^{-1}$, which agrees very well with the phase propagation of the SLA signal discussed in Sect. 4.2.2.

\subsection{Response of hydrographic conditions to the PCUC intensification}

In the following, we analyse the changes in hydrographic conditions co-occurring with the increase of the alongshore flow. Lower near-surface temperatures near the coast compared to offshore (Figs. 1, 9a and b) indicated active upwelling during the observational programme. While the upwelling signal was restricted to the upper $50 \mathrm{~m}$, nearcoastal water masses between 50 and $300 \mathrm{~m}$ were significantly warmer compared to water masses offshore (Fig. 9a). During the intensified PCUC period (Fig. 9b, e, h), the cross-shore temperature gradient intensified, leading to an increased downward displacement of isopycnals and isotherms near the coast (Fig. 9b). There, the associated warming signal between 100 and $200 \mathrm{~m}$ depth was up to $0.5^{\circ} \mathrm{C}$. Note that during the PCUC intensified period, near-coastal surface temperatures decreased.

Salinity featured a shallow subsurface salinity maximum at about $25 \mathrm{~m}$ depth originating offshore and extending over the slope and shelf (Fig. 9d and e). As for temperature, cross- 


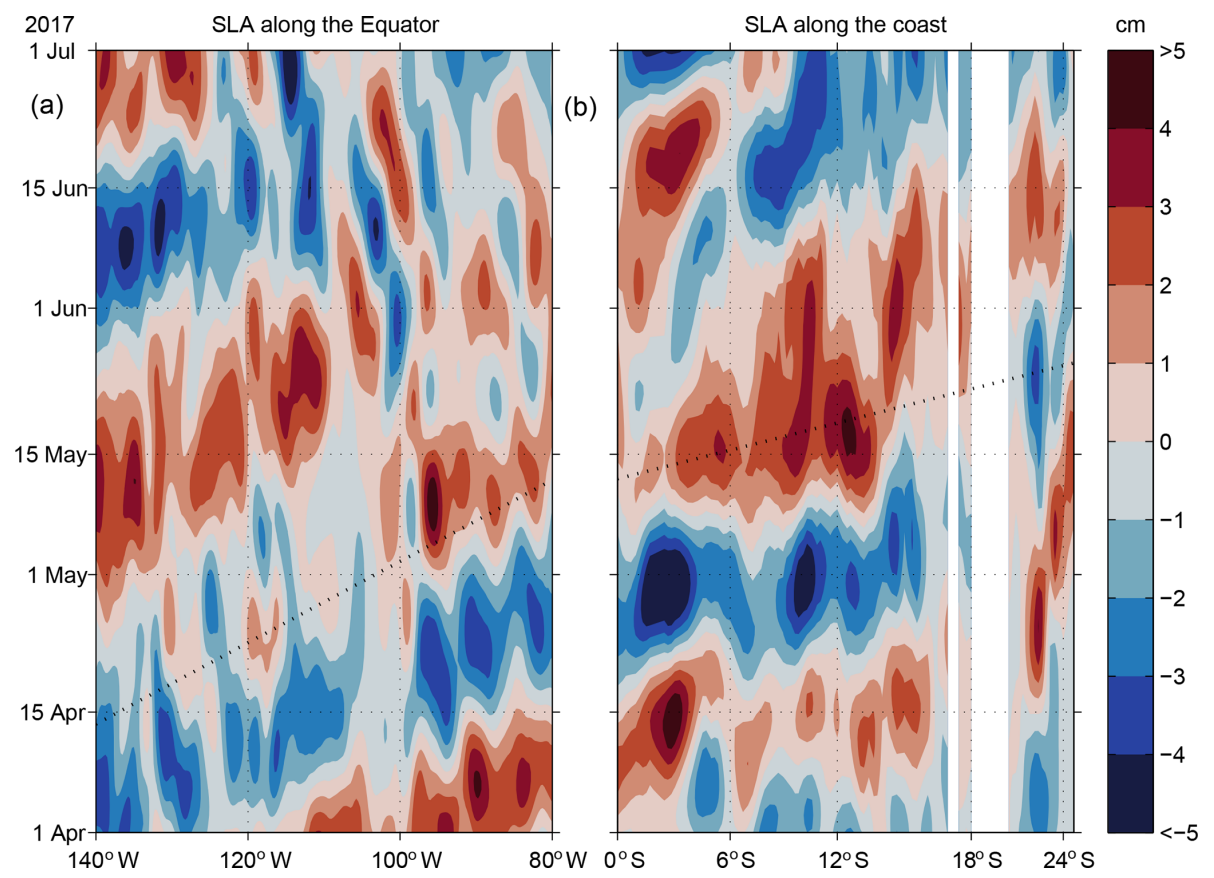

Figure 7. Bandpass-filtered (20-90 d) sea level anomaly along the eastern equatorial Pacific averaged between $0.25^{\circ} \mathrm{N}$ and $0.25^{\circ} \mathrm{S}(\mathbf{a})$ and along the western coast of South America (b) averaged over the two grid points closest to the coastline. The propagation of a first-mode equatorial Kelvin wave and CTW are shown as dotted black lines; the phase speed of the equatorial wave is $2.7 \mathrm{~m} \mathrm{~s}^{-1}$ (Yu and McPhaden, 1999) and $3.1 \mathrm{~m} \mathrm{~s}^{-1}$ for CTWs (see Fig. 8b).

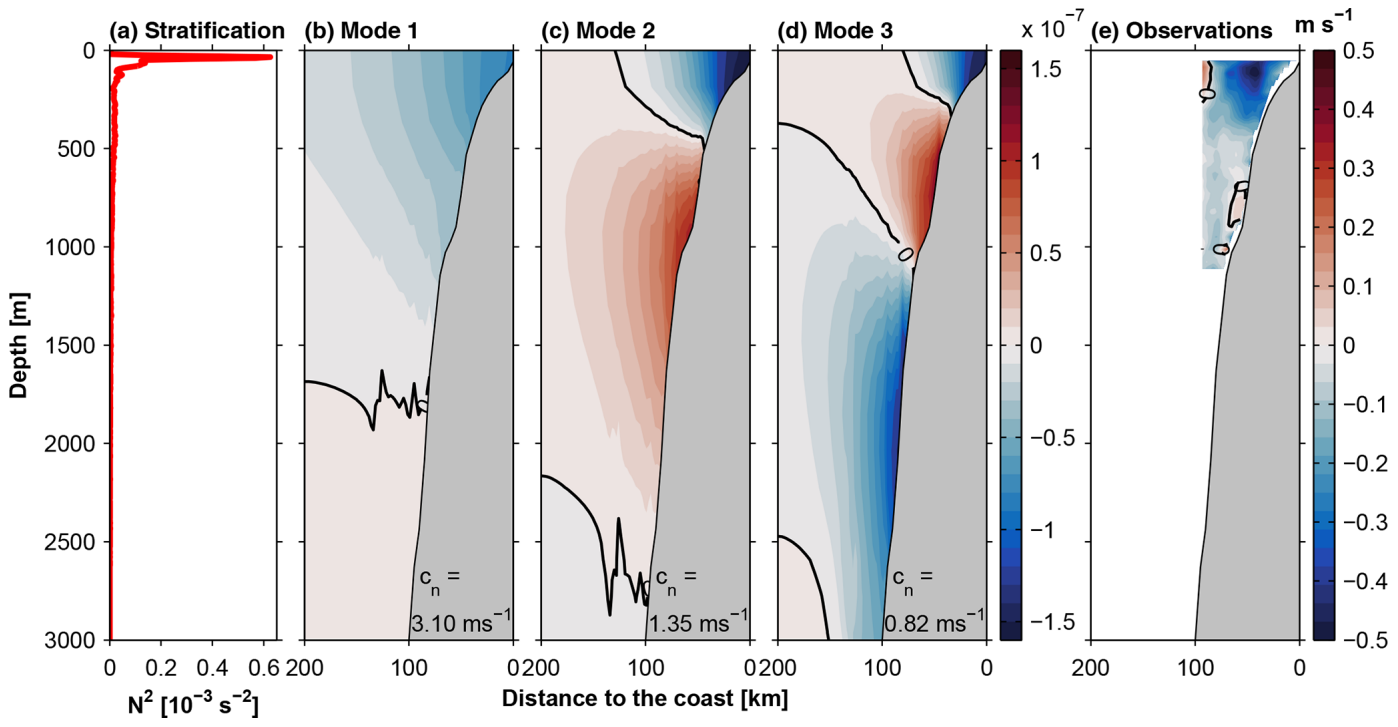

Figure 8. Profile of stratification $\left(\mathrm{N}^{2}\right)$ (a) and cross-shore-depth structure of alongshore velocity (arbitrary amplitude) obtained for the first three CTW modes (b-d). Panel (e) shows the difference of observed alongshore velocity between 18 April-3 May and 12-26 May 2017. Note that the CTW phase speeds $c_{n}$ are given in the lower right corner of the respective velocity structure panel. 
shore salinity gradients were evident between 50 and $300 \mathrm{~m}$ depth with higher salinities near the coast which intensified when the PCUC increased. At the same time, salinity at the upper shelf decreased (Fig. 9f).

Distributions of oxygen concentrations were characterized by a sharp oxycline above the anoxic OMZ (Fig. $9 g$ and $h$ ). During the weak PCUC period, oxygen concentrations decreased from slightly supersaturated at the surface to anoxia within the upper $100 \mathrm{~m}$ of the water column (Fig. 9g). Between 450 and $500 \mathrm{~m}$, oxygen concentrations started to increase again to detectable values (Fig. 9g). When the poleward flow intensified, oxygen levels of waters below about $100 \mathrm{~m}$ depth increased (Fig. 9i) and low-oxygen waters were found deeper in the water column than previously (Fig. 9h). Part of the increased oxygen levels were due to the downward displacement of the isopycnals (Fig. 9h), particularly in the near-bottom waters above the continental slope. There, oxygen concentrations larger than $2 \mu \mathrm{mol} \mathrm{kg}^{-1}$ were observed at $200 \mathrm{~m}$ depth in bottom waters (Fig. 9h), a depth range that is usually occupied by anoxic water masses. Such ventilation events have significant consequences for benthic and pelagic biota and for biogeochemical processes in that depth range, as further discussed below.

In the upper water column above $400 \mathrm{~m}$, waters with potential density anomalies larger than $25.9 \mathrm{~kg} \mathrm{~m}^{-3}$ were predominantly ESSW (Fig. 10). ESSW originates from the equatorial current system. It is characterized by a linear relationship of temperature and salinity in the temperature range $8-14{ }^{\circ} \mathrm{C}$ and salinity range $34.6-35.0$ (e.g. Grados et al., 2018). Lower salinity eastern South Pacific Intermediate Water (temperature range $12-14^{\circ} \mathrm{C}$, salinity 34.8 ), which is also situated in the depth range mentioned above, was only observed in the hydrographic data from two offshore stations (Fig. 10a). The dominance of ESSW was not affected by the increasing poleward velocities (Fig. 10b) and most profiles followed the same temperature and salinity relationship in both phases. In fact, during PCUC intensification, the ESSW was the sole water mass in the upper $400 \mathrm{~m}$ within $80 \mathrm{~km}$ of the coast (Fig. 10b).

\subsection{Response of nutrient biogeochemistry to PCUC intensification}

Nutrients are supplied to the upwelling region by poleward transport within the PCUC. In the following, we relate the observed changes in nutrient concentrations to the PCUC variability and to microbially mediated biogeochemical processes (Sect. 3.2.1). In the anoxic core of the OMZ, denitrification represents a prominent process of anaerobic organic matter degradation and a major sink for reactive nitrogen (Kalvelage et al., 2013; Gruber, 2008). During denitrification, nitrate is stepwise reduced to $\mathrm{N}_{2}$, with nitrite and nitrous oxide, as important intermediate products. Subsequently, nitrite is either further reduced to $\mathrm{N}_{2}$ via denitrification or may be used in the microbially driven anaerobic oxidation of $\mathrm{NH}_{4}^{+}$to $\mathrm{N}_{2}$ known as annamox (anaerobic ammonium oxidation) (Kuypers et al., 2005; Lam et al., 2009), which leads to a loss of reactive nitrogen. The distributions of nitrate (Fig. 11a and b) and nitrite concentrations (Fig. 11d and e) demonstrate the transformation of nitrate to nitrite. In the open ocean, nitrate increases with depth in the upper $1000 \mathrm{~m}$, whereas on the Peruvian margin a nitrate minimum in the anoxic core of the $\mathrm{OMZ}$ is pronounced at $12^{\circ} \mathrm{S}$ (Fig. 11a and b), co-occurring with a maximum in nitrite.

During the period of PCUC intensification, nitrate concentrations on the shelf and upper slope increased (Fig. 11a and b). Before the intensification, nitrate concentrations in the upper $300 \mathrm{~m}$ of the water column hardly exceeded $25 \mu \mathrm{mol} \mathrm{kg}{ }^{-1}$ and particularly low concentrations were found in bottom waters on the shelf, where a local minimum with less than $15 \mu \mathrm{mol} \mathrm{kg}{ }^{-1}$ is reached (Fig. 11a). As the PCUC intensified, nitrate concentrations between 50 and $250 \mathrm{~m}$ mostly exceeded $25 \mathrm{mmol} \mathrm{kg}^{-1}$ (Fig. 11b). Throughout this part of the section, the increase was higher than $2.5 \mu \mathrm{mol} \mathrm{kg} \mathrm{kg}^{-1}$ (Fig. 11c) and exceeded $5 \mu \mathrm{mol} \mathrm{kg} \mathrm{kg}^{-1}$ in some areas.

On the other hand, nitrite concentrations in deeper and bottom waters on the shelf and upper slope were reduced during the intensified PCUC period (Fig. 11d and e). In general, nitrite concentrations in oxygenated waters $\left(\mathrm{O}_{2}>2 \mu \mathrm{mol} \mathrm{kg}{ }^{-1}\right.$ were less than $1 \mu \mathrm{mol} \mathrm{kg}-1$, which is likely due to nitrification. In the anoxic core of the OMZ, the nitrite distribution featured two maxima: one in the upper part of the OMZ between 150 and $200 \mathrm{~m}$ depth and another in the centre of the $\mathrm{OMZ}$ at $300 \mathrm{~m}$ depth, both having concentrations of up to $5 \mu \mathrm{mol} \mathrm{kg}{ }^{-1}$. During the PCUC intensification period, the upper boundary of nitrite containing water was displaced downwards (Fig. 11e) following the displacement of anoxic waters (Fig. 9h). This caused a nitrite decrease exceeding $2 \mu \mathrm{mol} \mathrm{kg} \mathrm{kg}^{-1}$ in the deeper and bottom water on the continental slope at about $200 \mathrm{~m}$ depth (Fig. 11f).

Ammonium concentrations were generally low or undetectable. Concentrations in excess of $0.4 \mu \mathrm{mol} \mathrm{kg}{ }^{-1}$ occurred only close to the surface on the upper shelf (Fig. $11 \mathrm{~g}$ and $\mathrm{h}$ ). It should be noted that in the Peruvian upwelling region, the sediments are a strong source of ammonium (e.g. Sommer et al., 2016). However, despite taking water samples for nutrient analysis very close to the sea floor, elevated ammonium concentrations could not be detected, suggesting a fast removal by annamox of ammonium which was released from the sediments. In the event that oxygen was present, ammonium could also have been nitrified to nitrate.

Phosphate concentrations did not change considerably during the PCUC intensification period (Fig. $11 \mathrm{j}$ and $\mathrm{k}$ ). Concentrations were low at the surface and increased to $2 \mu \mathrm{mol} \mathrm{kg}{ }^{-1}$ at $50 \mathrm{~m}$ depth. Within the upper OMZ, the concentrations were higher offshore than onshore (Fig. 11j and k). When the PCUC intensified, concentrations decreased in approximately the same region in which the nitrate increase occurred (Fig. 111). A phosphate decrease of up to 

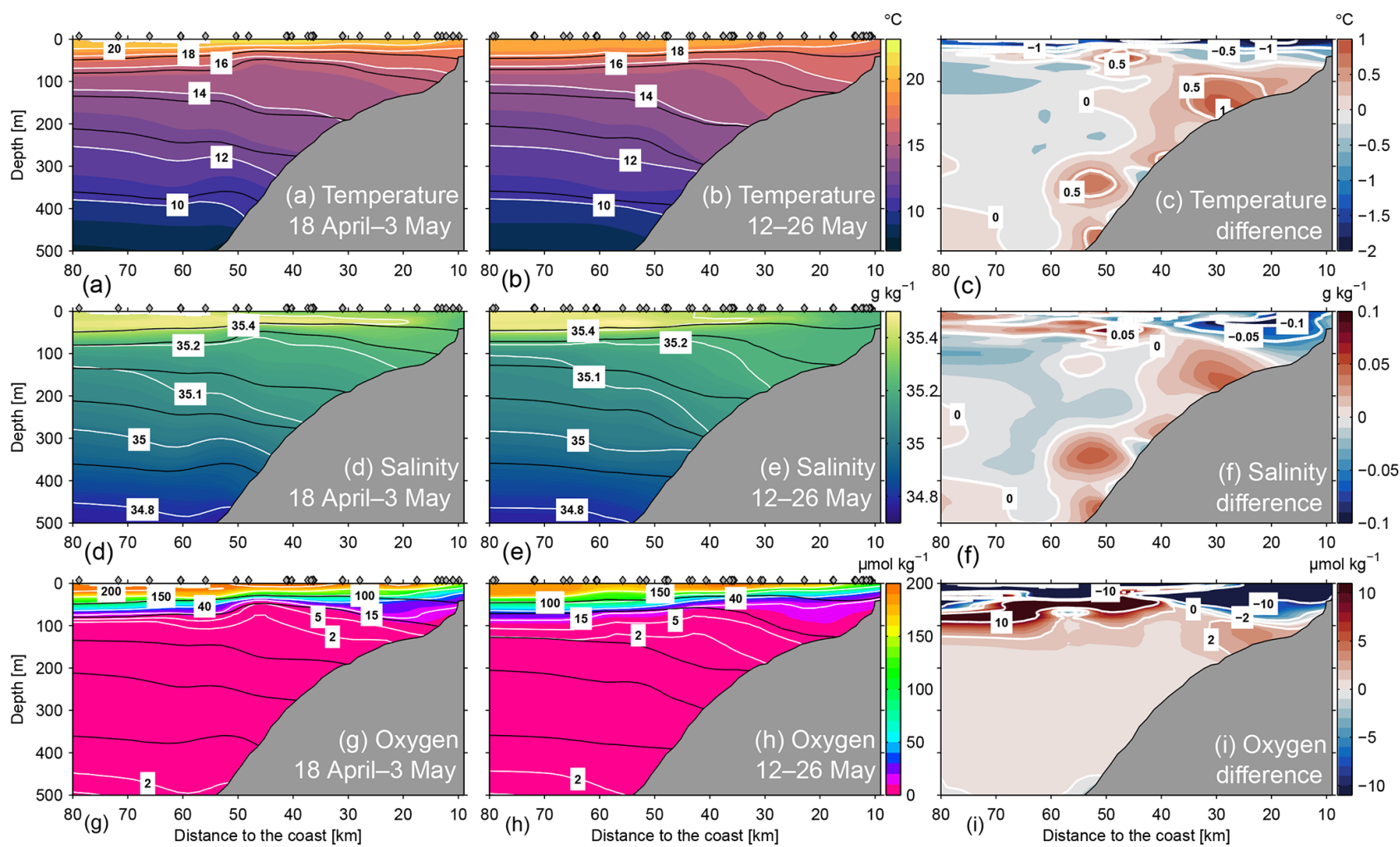

Figure 9. Conservative temperature (a-c), absolute salinity (d-f) and oxygen (g-i) at $12^{\circ} \mathrm{S}$ during 18 April-3 May 2017 (a, d, g) and $12-$ 26 May 2017 (b, e, h). The difference of the respective characteristic between the two periods is indicated in panels (c), (f) and (i). Black lines indicate the distribution of isopycnals $\left(\sigma_{\theta}\right)$ at 25.6, 25.9, 26.2, 26.4 and $26.7 \mathrm{~kg} \mathrm{~m}^{-3}$. Grey diamonds mark positions of CTD stations.

(a) 18 April-3 May

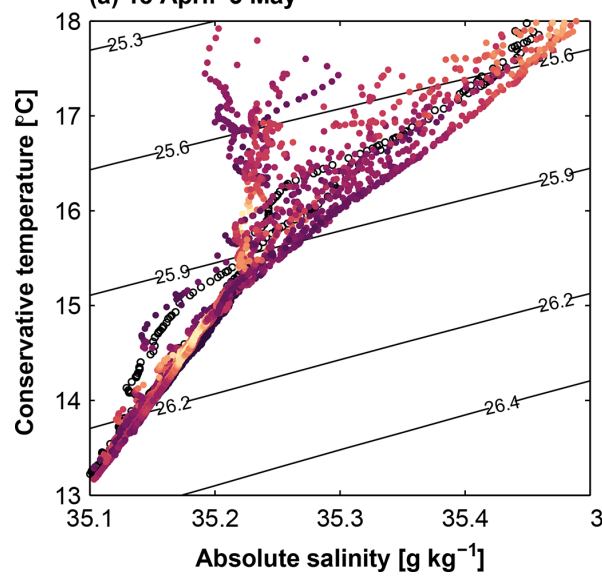

(b) 12-26 May

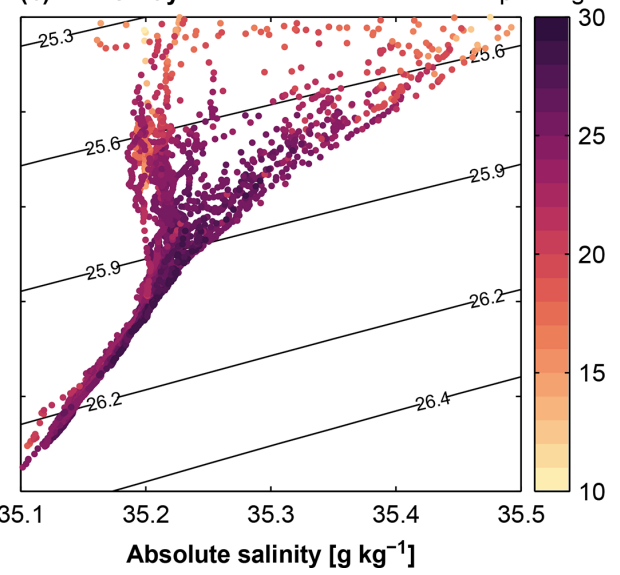

Figure 10. Conservative temperature - absolute salinity diagram between 50 and $300 \mathrm{~m}$ depth for CTD profiles between the 100 and $400 \mathrm{~m}$ isobaths during 18 April-3 May 2017 (a) and 12-26 May 2017 (b). Colour code depicts nitrate concentrations. Black contours indicate isopycnals $\left(\sigma_{\theta}\right)$ in $\mathrm{kg} \mathrm{m}^{-3}$.

$0.3 \mu \mathrm{mol} \mathrm{kg}-1$ occurred in bottom waters on the shelf at water depths shallower than $100 \mathrm{~m}$.

The nitrogen deficit $\left(N_{\text {def }}\right.$, Sect. 3.2.1) was reduced during the period of PCUC intensification (Fig. 11m-o). Whilst the PCUC was weak, waters having a nitrogen deficit between
5 and $15 \mu \mathrm{mol} \mathrm{kg}-1$ were present at depths between 100 and $400 \mathrm{~m}$. Maximum values were found on the continental shelf and offshore between 100 and $200 \mathrm{~m}$ (Fig. 11m). During the PCUC intensification period, the nitrogen deficit maximum at the continental shelf disappeared and low-deficit waters 

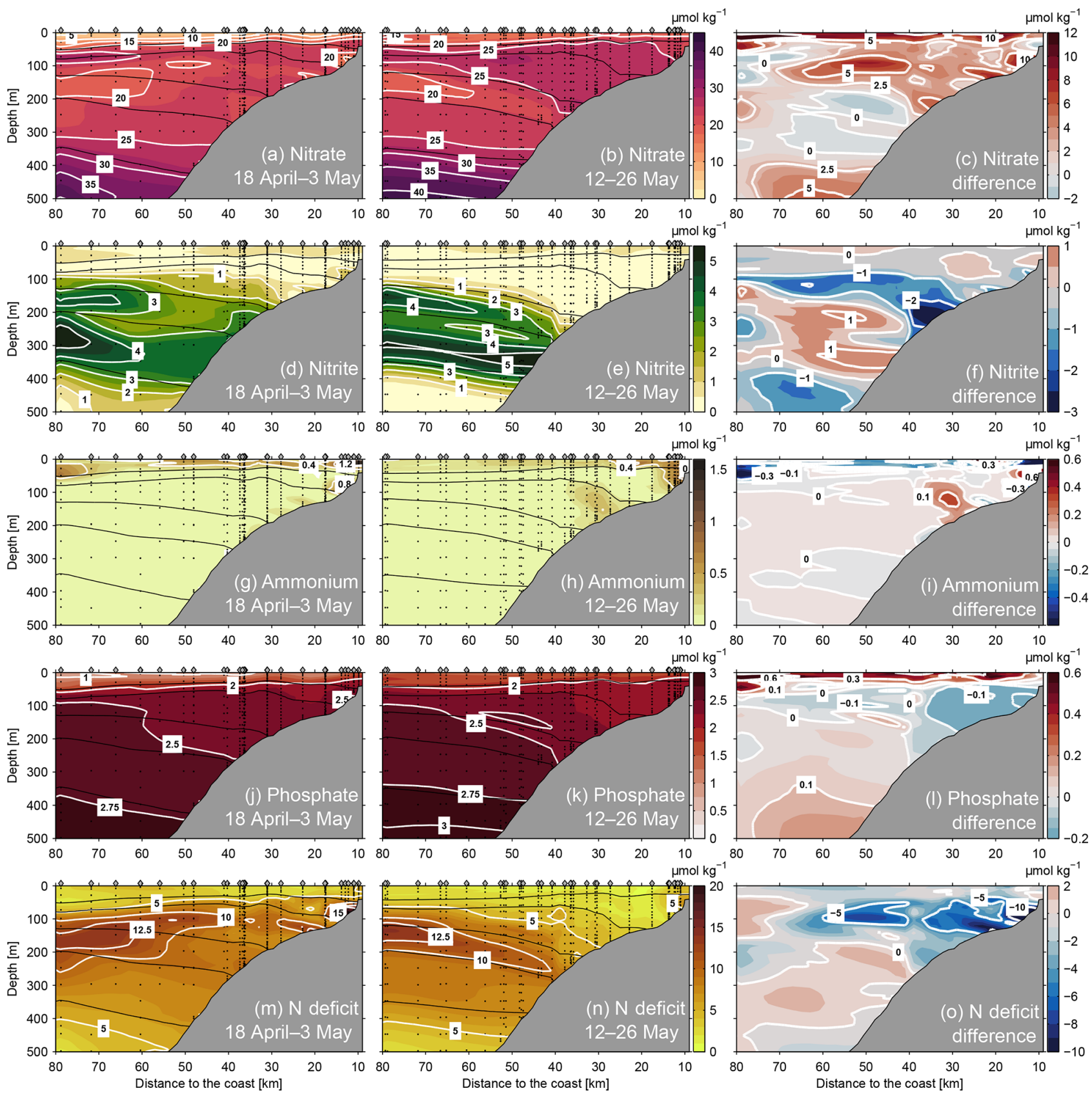

Figure 11. Nitrate (top row), nitrite (second row), ammonium (third row), phosphate (fourth row) concentrations and nitrogen deficit (bottom row) at $12^{\circ} \mathrm{S}$ during 18 April-3 May 2017 (left panels) and 12-26 May 2017 (middle panels). Concentration difference of the respective parameters between the two time periods are shown in the right panels. Black lines indicate the distribution of isopycnals $\left(\sigma_{\theta}\right)$ at $25.6,25.9$, $26.2,26.4$ and $26.7 \mathrm{~kg} \mathrm{~m}^{-3}$. Grey diamonds mark the positions of CTD stations and black circles mark the position of bottle samples in the water column.

$\left(N_{\text {def }}<5 \mu \mathrm{mol} \mathrm{kg}-1\right)$ occupied the upper $200 \mathrm{~m}$ of the water column inshore of $40 \mathrm{~km}$ (Fig. 11n). The reduced nitrogen deficit was due increased nitrate concentrations (Fig. 11c) and somewhat reduced phosphate concentrations (Fig. 111). Furthermore, the region with reduced $N_{\text {def }}$ agrees well with the location of maximum poleward flow during the PCUC intensification period (Fig. 3b). This suggests that poleward advection in the intensified PCUC was the main cause for the observed changes in biogeochemical properties. 


\section{Summary and discussion}

Measurements from an intensive physical and biogeochemical shipboard sampling programme off Peru at $12^{\circ} \mathrm{S}$ carried out between 7 April and 24 June 2017 are used to analyse intraseasonal variability of the eastern boundary circulation and associated changes in hydrography and nutrient distributions. Our most prominent finding is an intensification of poleward flow within the depth range occupied by the PCUC that started early May 2017 and lasted for about $35 \mathrm{~d}$. During this period, poleward velocities occupied the whole water column above $1000 \mathrm{~m}$ depth and extended to more than $80 \mathrm{~km}$ offshore. Maximum velocities in the PCUC core between 50 and $100 \mathrm{~m}$ depth were above $0.5 \mathrm{~m} \mathrm{~s}^{-1}$, about 5 times larger than the respective climatological PCUC velocities (Chaigneau et al., 2013) at this latitude.

The elevated poleward velocities were most likely caused by a downwelling CTW. Satellite SLA data indicate a positive anomaly propagating eastward from the eastern equatorial Pacific to the South American coast and subsequently poleward to beyond $14^{\circ} \mathrm{S}$. An elevated westerly wind anomaly on the Equator in the central Pacific that occurred in April 2017 is suggested to have excited the initial Kelvin wave. Wind stress and wind stress curl variability along the South American coast did not impact the CTW nor the elevated alongshore velocities. The phase speed of the SLA signal propagation along the South American coast is consistent with a first-vertical-mode CTW. Similarly, the vertical distribution of the poleward velocity anomaly at the eastern boundary generally agreed with the cross-shoredepth velocity structure of a first-mode CTW.

While temperature and salinity conditions remained almost unaltered, the enhanced poleward water mass advection due to the CTW induced changes in the distribution of oxygen and nutrient along the eastern boundary. Below $100 \mathrm{~m}$ depth, oxygen concentrations increased and the upper boundary of anoxic water $\left(\mathrm{O}_{2}>2 \mu \mathrm{mol} \mathrm{kg}^{-1}\right)$ deepened by about $50 \mathrm{~m}$ due to both, the downward displacement of the isopycnals in the thermocline and the advection of ESSW having higher oxygen concentrations. Similarly, nitrate concentrations increased during the period of intensified poleward flow, while phosphate concentrations and nitrogen deficit decreased (Fig. 12).

Similar to our results, previous studies have identified the first vertical mode CTWs to dominate intraseasonal variability in the eastern South Pacific based on tide gauge and SLA observations (e.g. Brink, 1982; Shaffer et al., 1997) and model results (Illig et al., 2018b). However, there is disagreement in the details of the observed cross-shore-depth alongshore velocity structure of the CTW and the velocity structure of a first-vertical-mode solution of a linear wave model using local stratification and topography suggesting that additional dynamical processes are important.

A possible explanation of the poor agreement is interaction of the CTW with local topography. North of our sam- pling site, the continental slope bends offshore at depths between 500 and $1000 \mathrm{~m}$ (Fig. 1, insert) while the shelf narrows to the south. Changes in coastline, shelf width and along-slope bathymetry lead to a transfer of CTW energy into higher modes (scattering) and upstream backscattering (Wang, 1980; Wilkin and Chapman, 1990; Kämpf, 2018; Brunner et al., 2019). The influence of changes in shelf width on the upstream alongshore flow structure can extend to $200 \mathrm{~km}$ upstream (Wilkin and Chapman, 1990) but, due to relative smooth downstream topography, is likely not relevant here. However, the bend of the continental slope and other topographic irregularities north of our sampling site may stimulate energy transfer into high-vertical-mode CTWs. In turn, the superposition of several vertical modes could explain the observed elevated poleward flow between 50 and $300 \mathrm{~m}$ depth (Figs. 3 and 12) that cannot be explained by a first-mode CTW. In fact, a recent model study suggests that differences between the theoretical CTW solutions and observations are predominately due to wave scattering (Brunner et al., 2019).

The temperature and salinity conditions on the shelf remain almost unchanged despite the strongly intensified poleward flow, suggesting that the same water mass was advected within the boundary current regime during both observational periods. However, during the presence of the CTW, SSTs were lower than in the period prior to the wave. This is a somewhat unexpected result because downwelling CTWs weaken coastal upwelling due to the downward displacement of the thermocline which should lead to warmer SSTs and earlier in March 2017 downwelling CTWs contributed to the anomalously high SST in the coastal El Niño (Echevin et al., 2018; Peng et al., 2019). However, previous studies have shown that the impact of CTWs on intraseasonal SST variability off Peru is limited (Dewitte et al., 2011; Illig et al., 2014). Specifically, in May 2017 SST reduction agrees with both the seasonal cycle (Graco et al., 2017) and the decline of the warm Coastal El Niño with peak SST in March (e.g. Garreaud, 2018).

Changes in oxygen concentrations due to the CTW event were rather small. In the water column between 100 and $200 \mathrm{~m}$ depth, oxygen concentrations increased by 1 to $10 \mu \mathrm{mol} \mathrm{kg}{ }^{-1}$, only. However, the limited impact of the CTW on the oxygen distribution is likely related to high oxygen concentrations present at the study site before the wave passage. Previous measurement programmes in this area found the mean depth of the upper boundary of the OMZ on the shelf at about $50 \mathrm{~m}$ depth (Gutiérrez et al., 2008; Dale et al., 2015; Graco et al., 2017) but deepening to $200 \mathrm{~m}$ or more during El Niño-Southern Oscillation (ENSO) years (e.g. Levin et al., 2002; Espinoza-Morriberón et al., 2019). In particular, Dale et al. (2015) found oxygen levels below the detection limit between 30 and $400 \mathrm{~m}$ depth during previous measurement programmes along $12^{\circ} \mathrm{S}$. It is thus likely that the prevailing elevated oxygen concentrations are related to the coastal El Niño event in the same way that 

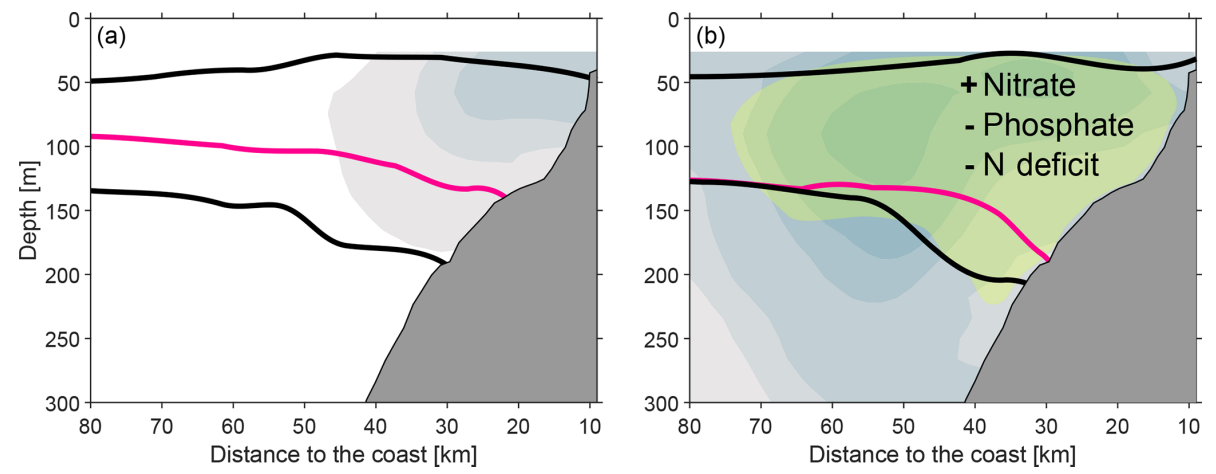

Figure 12. Schematic of the conditions off Peru during the initial phase of weak PCUC flow (a) and strong PCUC flow (b). Alongshore circulation is shown as colour shading, two isopycnals are shown in black, and the top of the anoxic zone is shown in magenta (represented by the $2 \mu \mathrm{mol} \mathrm{kg}^{-1}$ isoline). The green shaded area in panel (b) shows the region of increased nitrate, decreased phosphate concentrations and decreased nitrogen deficit.

canonical El Niño events are related to enhanced oxygenation (Helly and Levin, 2004; Espinoza-Morriberón et al., 2019). Despite small oxygen concentration changes, the upper boundary of anoxic water deepened by about $50 \mathrm{~m}$ during the presence of the CTW (Fig. 12). The change from anoxic conditions to suboxic conditions with oxygen concentrations $\left(\mathrm{O}_{2}>2 \mu \mathrm{mol} \mathrm{kg}^{-1}\right)$ has important consequences for biogeochemical processes and the benthic and pelagic communities (e.g. Gutiérrez et al., 2008). This study thus confirms previous suggestions that CTW led to episodic oxygenation events that are vital for colonization of invertebrates and other biotas within the predominately anoxic regions of the benthos and the water column above.

The increase in nitrate concentrations and the reduced nitrogen deficit are likely caused by the faster advection during the intensified flow period. The nitrate concentrations in the ESSW increase and waters with the same temperaturesalinity properties are richer in nitrate following the intensification of the PCUC (Fig. 10), indicating the nitrate increase was not due to a different source of advected water. Along the ESSW pathway within the PCUC from the Equator to $12^{\circ} \mathrm{S}$, the nitrogen deficit increases while nitrate concentrations decrease (Silva et al., 2009; Zamora et al., 2012; Kalvelage et al., 2013). The resulting nitrogen deficit accumulates with time during the poleward advection. Thus, an intensified PCUC increases the poleward advection of water with a lower nitrogen deficit. This can be verified by investigating the advection timescales. The alongshore distance from the Equator to the $12^{\circ} \mathrm{S}(1800 \mathrm{~km})$ and a PCUC velocity of $0.4 \mathrm{~m} \mathrm{~s}^{-1}$ yields a timescale of $52 \mathrm{~d}$, while a timescale of $160 \mathrm{~d}$ results from a velocity of $0.13 \mathrm{~m} \mathrm{~s}^{-1}$ representing maximum climatological velocity (Chaigneau et al., 2013). Using a rate for $\mathrm{N}$ loss of $48 \mathrm{nmol} \mathrm{N} \mathrm{L}^{-1} \mathrm{~d}^{-1}$ (combined anammox and denitrification rates in the coastal $\mathrm{OMZ}$ from Kalvelage et al., 2013) results in an N-loss difference of $5.2 \mu \mathrm{mol} \mathrm{N} \mathrm{L}^{-1}$ due to the lower flow velocities. Indeed, the reduction of the nitrogen deficit by about $5 \mu \mathrm{mol} \mathrm{Ng}^{-1}$, as observed throughout much of the PCUC core during the presence of the CTW, closely relates to this estimate. The sediments off Peru subjected to oxygen-depleted bottom waters release phosphate into the water column (Noffke et al., 2012; Lomnitz et al., 2016) that also contributes to the nitrogen deficit. Faster advection leads to a reduced accumulation of phosphate that is released from the sediments with lower phosphate concentrations during the strong PCUC flow. However, the increase of nitrate exceeds the phosphate decrease by about 5 to $0.1 \mu \mathrm{mol} \mathrm{kg}{ }^{-1}$, a ratio higher than the nitrogento-phosphorus ratio given in Eq. (1). Therefore, changes of nitrate concentration dominate the reduction of the nitrogen deficit.

The increase in nitrate by the downwelling CTW implies that the change in alongshore advection with the increased flow is more important for the nitrate balance than downwelling. The downwelling would displace the nutricline and thus transfer low-nutrient surface waters downwards, lowering nutrient concentrations, which was not observed. The decline in nitrate concentrations during El Niño events has been associated with a nutricline displacement due to downwelling CTWs on interannual timescales (Graco et al., 2017; Espinoza-Morriberón et al., 2017). However, focusing on intraseasonal timescales, Echevin et al. (2014) modelled an almost cancelling of horizontal and vertical (i.e. nutricline movement) advection and a fast-mode CTW not impacting nutricline depth. In a model study in the Atlantic Ocean, where nitrate decreases poleward as well, it was shown that the total effect of CTWs on nitrate concentrations varies regionally due to a different balance of horizontal and vertical advection, but the horizontal advection always led to an increase in nitrate (Bachèlery et al., 2016).

The changes in redox state in the water column and especially bottom waters affect the biogeochemical cycling in the sediment as well. Because microbial storage of nitrate and nitrite by microorganisms in the sediment can sustain vigorous $\mathrm{N}$ turnover even in the absence of bottom water nitrate 
and nitrite (Dale et al., 2016; Sommer et al., 2016), episodic events of nitrogen supply can be associated with continuous benthic nitrogen cycling. The absence of nitrate supply due to the absence of CTWs over longer time periods favours the depletion of nitrate in the water column as observed by Sommer et al. (2016) and may lead ultimately to the development of sulfidic events (Schunck et al., 2013; Dale et al., 2016; Callbeck et al., 2018).

\section{Conclusions}

Based on extensive physical and biogeochemical sampling, we describe and analyse the evolution of circulation, hydrography and biogeochemistry off Peru in 2017. Poleward velocities within the PCUC intensified in May 2017 to several times the reported climatological mean. This increased flow occurs during a limited time period in May in between weaker poleward transport in April and late June. The propagation velocity of positive SLA along the Equator and coastline suggests that the intensified current is caused by a poleward propagating downwelling CTW of the first baroclinic mode forced around $160^{\circ} \mathrm{W}$ at the Equator that caused a positive SLA signal east of $95^{\circ} \mathrm{W}$. The transition of the circulation from a weak poleward flow to strong poleward flow decreased the timescale of alongshore advection from the equatorial current regime to the study site at $12^{\circ} \mathrm{S}$.

The downwelling CTW is not associated with strong vertical displacements of waters; instead, the advection caused by the intensified PCUC is more important. For parameters without strong horizontal gradients, an increase in PCUC flow does not cause pronounced changes in the advection. In this study, this applied to the conservative properties of temperature and salinity as well as for oxygen where alongshore gradients are weak (Zamora et al., 2012). For these parameters, there are no large differences between both circulation phases that can be attributed clearly to the altered circulation. Yet concentrations of nutrients are influenced by shorter transit times, being less altered by biogeochemical cycling. This leads to an increase of bioavailable nitrogen in the OMZ (Fig. 12) and its biogeochemistry is strongly changed by the increased ratio of nitrogen to phosphorus related to the increased advection.

For the period from April to May 2017, our study suggests an increase in nitrate levels due to the passage of an intraseasonal downwelling CTW. This contrasts with the decrease observed previously on interannual timescales caused by downwelling CTWs (Graco et al., 2017). This shows that the impact of CTWs on nutrient biogeochemistry is a complex balance between different factors, with potentially different outcome on different timescales. Analysing the processes associated with individual intraseasonal waves is also necessary to understand the interannual effect of CTWs, which is based on varying occurrence of such waves in different years.
The high variability of circulation, nutrients and the nitrogen deficit demonstrates the need for temporally resolved sampling as an individual section recorded may be very different from the situation a few weeks later. Quantification of intraseasonal variability in CTWs and their impact is - other than in modelling studies (e.g. Echevin et al., 2014) - only possible by sampling at high temporal resolution.

Data availability. Ship-based observations are available at PANGAEA (https://doi.org/10.1594/PANGAEA.903828, Lüdke et al., 2019). Global Ocean Gridded L4 sea surface heights are made available by the EU Copernicus Marine Service (CMEMS). NOAA ERSSTv5 data are made available by the NOAA National Centers for Environmental Information. ASCAT data were obtained from the Centre de Recherche et d'Exploitation Satellitaire (CERSAT) at IFREMER, Plouzané (France).

Author contributions. JL carried out the data analysis and wrote the main manuscript. JL conceived the study with MD and with input by DC, ST and MV. MD and SS led the observational programme at sea. GK calibrated and processed the CTD. AD and SS provided the nutrient data. EPA provided the ammonium data. All co-authors reviewed the manuscript and contributed to the scientific interpretation and discussion.

Competing interests. The authors declare that they have no conflict of interest.

Special issue statement. This article is part of the special issue "Ocean deoxygenation: drivers and consequences - past, present and future (BG/CP/OS inter-journal SI)". It is a result of the International Conference on Ocean Deoxygenation, Kiel, Germany, 3-7 September 2018.

Acknowledgements. We thank the Peruvian authorities for the permission to carry out scientific work in their national waters. We thank the captains and the crew of R/V Meteor for their support during the cruises. We thank Regina Surberg and Bettina Domeyer for the nutrient analysis, all other people involved in the measurement programme and Rena Czeschel for post-cruise processing of the vmADCP data. We thank three anonymous reviewers for their helpful suggestions. Figures 1, 4, 6, 9, 10, 11 and 12 in this study use colour maps from the cmocean package (Thyng et al., 2016).

Financial support. This study was funded by the Deutsche Forschungsgemeinschaft as part of Sonderforschungsbereich 754 "Climate-Biogeochemistry Interactions in the Tropical Ocean". Sören Thomsen received funding from the European Commission (Horizon 2020 programme, MSCA-IF-2016, proposal no. WACO 749699: Fine-scale Physics, Biogeochemistry and Climate Change in the West African Coastal Ocean). 
The article processing charges for this open-access publication were covered by a Research Centre of the Helmholtz Association.

Review statement. This paper was edited by Minhan Dai and reviewed by three anonymous referees.

\section{References}

Albert, A., Echevin, V., Lévy, M., and Aumont, O.: Impact of nearshore wind stress curl on coastal circulation and primary productivity in the Peru upwelling system, J. Geophys. Res.-Oceans, 115, C12033, https://doi.org/10.1029/2010JC006569, 2010.

Bachèlery, M.-L., Illig, S., and Dadou, I.: Forcings of nutrient, oxygen, and primary production interannual variability in the southeast Atlantic Ocean, Geophys. Res. Lett., 43, 8617-8625, https://doi.org/10.1002/2016g1070288, 2016.

Bakun, A. and Nelson, C. S.: The Seasonal Cycle of WindStress Curl in Subtropical Eastern Boundary Current Regions, J. Phys. Oceanogr., 21, 1815-1834, https://doi.org/10.1175/15200485(1991)021<1815:TSCOWS>2.0.CO;2, 1991.

Becker, J. J., Sandwell, D. T., Smith, W. H. F., Braud, J., Binder, B., Depner, J., Fabre, D., Factor, J., Ingalls, S., Kim, S.-H., Ladner, R., Marks, K., Nelson, S., Pharaoh, A., Trimmer, R., Rosenberg, J. V., Wallace, G., and Weatherall, P.: Global Bathymetry and Elevation Data at 30 Arc Seconds Resolution: SRTM30_PLUS, Mar. Geod., 32, 355-371, https://doi.org/10.1080/01490410903297766, 2009.

Belmadani, A., Echevin, V., Dewitte, B., and Colas, F.: Equatorially forced intraseasonal propagations along the Peru-Chile coast and their relation with the nearshore eddy activity in 19922000: A modeling study, J. Geophys. Res.-Oceans, 117, C04025, https://doi.org/10.1029/2011JC007848, 2012.

Bentamy, A. and Fillon, D. C.: Gridded surface wind fields from Metop/ASCAT measurements, Int. J. Remote Sens., 33, 17291754, https://doi.org/10.1080/01431161.2011.600348, 2012.

Brandt, P., Bange, H. W., Banyte, D., Dengler, M., Didwischus, S.-H., Fischer, T., Greatbatch, R. J., Hahn, J., Kanzow, T., Karstensen, J., Körtzinger, A., Krahmann, G., Schmidtko, S., Stramma, L., Tanhua, T., and Visbeck, M.: On the role of circulation and mixing in the ventilation of oxygen minimum zones with a focus on the eastern tropical North Atlantic, Biogeosciences, 12, 489-512, https://doi.org/10.5194/bg-12-489-2015, 2015.

Brink, K. H.: A Comparison of Long Coastal Trapped Wave Theory with Observations off Peru, J. Phys. Oceanogr., 12, 897-913, https://doi.org/10.1175/15200485(1982)012<0897:ACOLCT>2.0.CO;2, 1982.

Brink, K. H.: Energy Conservation in CoastalTrapped Wave Calculations, J. Phys. Oceanogr., 19, 1011-1016, https://doi.org/10.1175/15200485(1989)019<1011:ECICTW>2.0.CO;2, 1989.

Brink, K. H.: Stable coastal-trapped waves with stratification, topography and mean flow, MBLWHOI Library, Woods Hole, https://doi.org/10.1575/1912/10527, 2018.

Brink, K. H. and Chapman, D. C.: Programs for computing properties of coastal-trapped waves and wind-driven motions over the continental shelf and slope, WHOI Technical Re- ports, Woods Hole Oceanographic Institution in Woods Hole, https://doi.org/10.1575/1912/5368, 1987.

Brink, K. H., Halpern, D., and Smith, R. L.: Circulation in the Peruvian upwelling system near $15^{\circ} \mathrm{S}$, J. Geophys. Res., 85, 40364048, https://doi.org/10.1029/jc085ic07p04036, 1980.

Brink, K. H., Halpern, D., Huyer, A., and Smith, R. L.: The physical environment of the Peruvian upwelling system, Prog. Oceanogr., 12, 285-305, https://doi.org/10.1016/00796611(83)90011-3, 1983.

Brunner, K., Rivas, D., and Lwiza, K. M. M.: Application of Classical Coastal Trapped Wave Theory to High-Scattering Regions, J. Phys. Oceanogr., 49, 2201-2216, https://doi.org/10.1175/JPOD-18-0112.1, 2019.

Callbeck, C. M., Lavik, G., Ferdelman, T. G., Fuchs, B., GruberVodicka, H. R., Hach, P. F., Littmann, S., Schoffelen, N. J., Kalvelage, T., Thomsen, S., Schunck, H., Löscher, C. R., Schmitz, R. A., and Kuypers, M. M. M.: Oxygen minimum zone cryptic sulfur cycling sustained by offshore transport of key sulfur oxidizing bacteria, Nat. Commun., 9, 1729, https://doi.org/10.1038/s41467-018-04041-x, 2018.

Carr, M.-E.: Estimation of potential productivity in Eastern Boundary Currents using remote sensing, Deep Sea Res. Part II, 49, 59-80, https://doi.org/10.1016/S0967-0645(01)00094-7, 2002.

Chaigneau, A., Dominguez, N., Eldin, G., Vasquez, L., Flores, R., Grados, C., and Echevin, V.: Near-coastal circulation in the Northern Humboldt Current System from shipboard ADCP data, J. Geophys. Res.-Oceans, 118, 5251-5266, https://doi.org/10.1002/jgrc.20328, 2013.

Chang, B. X., Devol, A. H., and Emerson, S. R.: Denitrification and the nitrogen gas excess in the eastern tropical South Pacific oxygen deficient zone, Deep Sea Res. Part I, 57, 1092-1101, https://doi.org/10.1016/j.dsr.2010.05.009, 2010.

Chavez, F. P., Bertrand, A., Guevara-Carrasco, R., Soler, P., and Csirke, J.: The northern Humboldt Current System: Brief history, present status and a view towards the future, Prog. Oceanogr., 79, 95-105, https://doi.org/10.1016/j.pocean.2008.10.012, 2008.

Dale, A. W., Sommer, S., Lomnitz, U., Montes, I., Treude, T., Liebetrau, V., Gier, J., Hensen, C., Dengler, M., Stolpovsky, K., Bryant, L. D., and Wallmann, K.: Organic carbon production, mineralisation and preservation on the Peruvian margin, Biogeosciences, 12, 1537-1559, https://doi.org/10.5194/bg-12-1537-2015, 2015.

Dale, A. W., Sommer, S., Lomnitz, U., Bourbonnais, A., and Wallmann, K.: Biological nitrate transport in sediments on the Peruvian margin mitigates benthic sulfide emissions and drives pelagic N loss during stagnation events, Deep Sea Res. Part I, 112, 123-136, https://doi.org/10.1016/j.dsr.2016.02.013, 2016.

Dengler, M. and Sommer, S.: Coupled benthic and pelagic oxygen, nutrient and trace metal cycling, ventilation and carbon degradation in the oxygen minimum zone of the Peruvian continental margin (SFB 754): Cruise No. M 13611 April-3 May 2017 Callao (Peru) - Callao Solute-Flux Peru I, METEOR-Berichte, https://doi.org/10.3289/CR_M136, 2019.

Dewitte, B., Illig, S., Renault, L., Goubanova, K., Takahashi, K., Gushchina, D., Mosquera, K., and Purca, S.: Modes of covariability between sea surface temperature and wind stress intraseasonal anomalies along the coast of Peru from satellite observations (2000-2008), J. Geophys. Res.-Oceans, 116, C04028, https://doi.org/10.1029/2010JC006495, 2011. 
Echevin, V., Albert, A., Lévy, M., Graco, M., Aumont, O., Piétri, A., and Garric, G.: Intraseasonal variability of nearshore productivity in the Northern Humboldt Current System: The role of coastal trapped waves, Cont. Shelf Res., 73, 14-30, https://doi.org/10.1016/j.csr.2013.11.015, 2014.

Echevin, V., Colas, F., Espinoza-Morriberon, D., Vasquez, L., Anculle, T., and Gutierrez, D.: Forcings and Evolution of the 2017 Coastal El Niño Off Northern Peru and Ecuador, Front. Mar. Sci., 5, 367, https://doi.org/10.3389/fmars.2018.00367, 2018.

Enfield, D. B., Cornejo-Rodriguez, M. D., Smith, R. L., and Newberger, P. A.: The equatorial source of propagating variability along the Peru coast during the 19821983 El Niño, J. Geophys. Res.-Oceans, 92, 14335-14346, https://doi.org/10.1029/JC092iC13p14335, 1987.

Espinoza-Morriberón, D., Echevin, V., Colas, F., Tam, J., Ledesma, J., Vásquez, L., and Graco, M.: Impacts of El Niño events on the Peruvian upwelling system productivity, J. Geophys. Res.-Oceans, 122, 5423-5444, https://doi.org/10.1002/2016JC012439, 2017.

Espinoza-Morriberón, D., Echevin, V., Colas, F., Tam, J., Gutierrez, D., Graco, M., Ledesma, J., and QuispeCcalluari, C.: Oxygen Variability During ENSO in the Tropical South Eastern Pacific, Front. Mar. Sci., 5, 526, https://doi.org/10.3389/fmars.2018.00526, 2019.

Fennel, W., Junker, T., Schmidt, M., and Mohrholz, V.: Response of the Benguela upwelling systems to spatial variations in the wind stress, Cont. Shelf Res., 45, 65-77, https://doi.org/10.1016/j.csr.2012.06.004, 2012.

Fischer, J., Brandt, P., Dengler, M., Müller, M., and Symonds, D.: Surveying the Upper Ocean with the Ocean Surveyor: A New Phased Array Doppler Current Profiler, J. Atmos. Ocean. Tech., 20, 742-751, https://doi.org/10.1175/15200426(2003)20<742:STUOWT>2.0.CO;2, 2003.

Garreaud, R. D.: A plausible atmospheric trigger for the 2017 coastal El Niño, Int. J. Climatol., 38, e1296-e1302, https://doi.org/10.1002/joc.5426, 2018.

Graco, M. I., Purca, S., Dewitte, B., Castro, C. G., Morón, O., Ledesma, J., Flores, G., and Gutiérrez, D.: The OMZ and nutrient features as a signature of interannual and low-frequency variability in the Peruvian upwelling system, Biogeosciences, 14, 4601-4617, https://doi.org/10.5194/bg-14-4601-2017, 2017.

Grados, C., Chaigneau, A., Echevin, V., and Dominguez, N.: Upper ocean hydrology of the Northern Humboldt Current System at seasonal, interannual and interdecadal scales, Prog. Oceanogr., 165, 123-144, https://doi.org/10.1016/j.pocean.2018.05.005, 2018.

Grasshoff, K., Ehrhardt, M., and Kremling, K.: Methods of seawater analysis, 63-72, Verlag Chemie, Weinheim, ISBN 3-527-25998$8,1983$.

Gruber, N.: The marine nitrogen cycle: overview and challenges, in: Nitrogen in the marine environment, vol. 2, edited by: Capone, D. G., Bronk, D. A., Mulholland, M., and Carpenter, E. J., pp. 1-50, Elsevier Amsterdam., ISBN 978-0-12-372522-6, 2008.

Gruber, N. and Sarmiento, J. L.: Global patterns of marine nitrogen fixation and denitrification, Global Biogeochem. Cy., 11, 235266, https://doi.org/10.1029/97GB00077, 1997.

Gruber, N. and Sarmiento, J. L.: Large-scale biogeochemicalphysical interactions in elemental cycles, in: THE SEA: Biological-Physical Interactions in the Oceans, vol. 12, edited by: Robinson, A. R., McCarthy, J. J., and Rothschild, B. J., 337399, Wiley, New York, ISBN 9780674017429, 2002.

Gunther, E. R.: A report on oceanographical investigations in the Peru Coastal Current, Discovery Rep., 13, 107-276, 1936.

Gutiérrez, D., Enríquez, E., Purca, S., Quipúzcoa, L., Marquina, R., Flores, G., and Graco, M.: Oxygenation episodes on the continental shelf of central Peru: Remote forcing and benthic ecosystem response, Prog. Oceanogr., 79, 177-189, https://doi.org/10.1016/j.pocean.2008.10.025, 2008.

Hauschildt, J., Thomsen, S., Echevin, V., Oschlies, A., José, Y. S., Krahmann, G., Bristow, L. A., and Lavik, G.: The fate of upwelled nitrate off Peru shaped by submesoscale filaments and fronts, Biogeosciences Discuss., https://doi.org/10.5194/bg2020-112, in review, 2020.

Helly, J. J. and Levin, L. A.: Global distribution of naturally occurring marine hypoxia on continental margins, Deep Sea Res. Part I, 51, 1159-1168, https://doi.org/10.1016/j.dsr.2004.03.009, 2004.

Hill, A. E., Hickey, B. M., Shillington, F. A., Strub, P. T., Brink, K. H., Barton, E. D., and Thomas, A. C.: Eastern Ocean Boundaries, in: The Seas: The Global Coastal Ocean, vol. 11, edited by: Robinson, A. R. and Brink, K. H., pp. 29-68, John Wiley, New York, ISBN 0-471-11545-2, 1998.

Holmes, R. M., Aminot, A., Kérouel, R., Hooker, B. A., and Peterson, B. J.: A simple and precise method for measuring ammonium in marine and freshwater ecosystems, Can. J. Fish. Aquat. Sci., 56, 1801-1808, https://doi.org/10.1139/f99-128, 1999.

Hood, E. M., Sabine, C. L., and Sloyan, B. M.: The GO-SHIP Repeat Hydrography Manual: a collection of expert reports and guidelines, Version 1, IOCCP Report 14, ICPO Publication Series 134, 2010.

Hormazabal, S., Shaffer, G., and Pizarro, O.: Tropical Pacific control of intraseasonal oscillations off Chile by way of oceanic and atmospheric pathways, Geophys. Res. Lett., 29, 51-54, https://doi.org/10.1029/2001GL013481, 2002.

Huang, B., Thorne, P. W., Banzon, V. F., Boyer, T., Chepurin, G., Lawrimore, J. H., Menne, M. J., Smith, T. M., Vose, R. S., and Zhang, H.-M.: NOAA Extended Reconstructed Sea Surface Temperature (ERSST), Version 5, https://doi.org/10.7289/V5T72FNM, 2017a.

Huang, B., Thorne, P. W., Banzon, V. F., Boyer, T., Chepurin, G., Lawrimore, J. H., Menne, M. J., Smith, T. M., Vose, R. S., and Zhang, H.-M.: Extended Reconstructed Sea Surface Temperature, Version 5 (ERSSTv5): Upgrades, Validations, and Intercomparisons, J. Climate, 30, 8179-8205, https://doi.org/10.1175/JCLI-D-16-0836.1, $2017 \mathrm{~b}$.

Illig, S., Dewitte, B., Goubanova, K., Cambon, G., Boucharel, J., Monetti, F., Romero, C., Purca, S., and Flores, R.: Forcing mechanisms of intraseasonal SST variability off central Peru in 2000-2008, J. Geophys. Res.-Oceans, 119, 3548-3573, https://doi.org/10.1002/2013JC009779, 2014.

Illig, S., Cadier, E., Bachèlery, M.-L., and Kersalé, M.: Subseasonal Coastal-Trapped Wave Propagations in the Southeastern Pacific and Atlantic Oceans: 1. A New Approach to Estimate Wave Amplitude, J. Geophys. Res.-Oceans, 123, 3915-3941, https://doi.org/10.1029/2017JC013539, 2018a.

Illig, S., Bachèlery, M.-L., and Cadier, E.: Subseasonal CoastalTrapped Wave Propagations in the Southeastern Pacific and Atlantic Oceans: 2. Wave Characteristics and Connection With 
the Equatorial Variability, J. Geophys. Res.-Oceans, 123, 39423961, https://doi.org/10.1029/2017JC013540, 2018 b.

Junker, T., Schmidt, M., and Mohrholz, V.: The relation of wind stress curl and meridional transport in the Benguela upwelling system, J. Mar. Syst., 143, 1-6, https://doi.org/10.1016/j.jmarsys.2014.10.006, 2015.

Kalvelage, T., Lavik, G., Lam, P., Contreras, S., Arteaga, L., Löscher, C. R., Oschlies, A., Paulmier, A., Stramma, L., and Kuypers, M. M.: Nitrogen cycling driven by organic matter export in the South Pacific oxygen minimum zone, Nat. Geosci., 6, 228-234, https://doi.org/10.1038/ngeo1739, 2013.

Kämpf, J.: On the Dynamics of Canyon-Flow Interactions, Journal of Marine Science and Engineering, 6, 129, https://doi.org/10.3390/jmse6040129, 2018.

Kämpf, J. and Chapman, P.: Upwelling Systems of the World: A Scientific Journey to the Most Productive Marine Ecosystems, Springer, Cham, ISBN 978-3-319-42522-1, 2016.

Karstensen, J., Schütte, F., Pietri, A., Krahmann, G., Fiedler, B., Grundle, D., Hauss, H., Körtzinger, A., Löscher, C. R., Testor, P., Vieira, N., and Visbeck, M.: Upwelling and isolation in oxygen-depleted anticyclonic modewater eddies and implications for nitrate cycling, Biogeosciences, 14, 2167-2181, https://doi.org/10.5194/bg-14-2167-2017, 2017.

Klenz, T., Dengler, M., and Brandt, P.: Seasonal Variability of the Mauritania Current and Hydrography at $18^{\circ} \mathrm{N}$, J. Geophys. Res.Oceans, 123, 8122-8137, https://doi.org/10.1029/2018jc014264, 2018.

Kuypers, M. M. M., Lavik, G., Woebken, D., Schmid, M., Fuchs, B. M., Amann, R., Jørgensen, B. B., and Jetten, M. S. M.: Massive nitrogen loss from the Benguela upwelling system through anaerobic ammonium oxidation, P. Natl. Acad. Sci., 102, 64786483, https://doi.org/10.1073/pnas.0502088102, 2005.

Lam, P., Lavik, G., Jensen, M. M., van de Vossenberg, J., Schmid, M., Woebken, D., Gutiérrez, D., Amann, R., Jetten, M. S. M., and Kuypers, M. M. M.: Revising the nitrogen cycle in the Peruvian oxygen minimum zone, P. Natl. Acad. Sci., 106, 4752-4757, https://doi.org/10.1073/pnas.0812444106, 2009.

Leth, O. and Middleton, J. F.: A numerical study of the upwelling circulation off central Chile: Effects of remote oceanic forcing, J. Geophys. Res.-Oceans, 111, C12003, https://doi.org/10.1029/2005JC003070, 2006.

Levin, L., Gutiérrez, D., Rathburn, A., Neira, C., Sellanes, J., Muñoz, P., Gallardo, V., and Salamanca, M.: Benthic processes on the Peru margin: a transect across the oxygen minimum zone during the 1997-1998 El Niño, Prog. Oceanogr., 53, 1-27, https://doi.org/10.1016/S0079-6611(02)00022-8, 2002.

Lomnitz, U., Sommer, S., Dale, A. W., Löscher, C. R., Noffke, A., Wallmann, K., and Hensen, C.: Benthic phosphorus cycling in the Peruvian oxygen minimum zone, Biogeosciences, 13, 13671386, https://doi.org/10.5194/bg-13-1367-2016, 2016.

Lüdke, J., Dengler, M., Sommer, S., Clemens, D., Thomsen, S., Krahmann, G., Dale, A. W., Achterberg, E. P., and Visbeck, M.: Influence of intraseasonal eastern boundary circulation variability on hydrography and biogeochemistry off Peru, PANGAEA, https://doi.org/10.1594/PANGAEA.903828, 2019.

Marchesiello, P., McWilliams, J. C., and Shchepetkin, A.: Equilibrium Structure and Dynamics of the California Current System, J. Phys. Oceanogr., 33, 753-783, https://doi.org/10.1175/15200485(2003)33<753:ESADOT>2.0.CO;2, 2003.
McCreary, J. P. and Chao, S.-Y.: Three-dimensional shelf circulation along an eastern ocean boundary, J. Mar. Res., 43, 13-36, https://doi.org/10.1357/002224085788437316, 1985.

McDougall, T. J. and Barker, P. M.: Getting started with TEOS10 and the Gibbs Seawater (GSW) oceanographic toolbox, SCOR/IAPSO WG 127, ISBN 978-0-646-55621-5, 2011.

Montes, I., Colas, F., Capet, X., and Schneider, W.: On the pathways of the equatorial subsurface currents in the eastern equatorial Pacific and their contributions to the PeruChile Undercurrent, J. Geophys. Res.-Oceans, 115, C09003, https://doi.org/10.1029/2009JC005710, 2010.

Moore, D. W. and Philander, S. G. H.: Modelling of the tropical ocean circulation, in The Sea, vol. 6, pp. 316-361, John Wiley, ISBN 0-471-31091-3, 1977.

Noffke, A., Hensen, C., Sommer, S., Scholz, F., Bohlen, L., Mosch, T., Graco, M., and Wallmann, K.: Benthic iron and phosphorus fluxes across the Peruvian oxygen minimum zone, Limnol. Oceanogr., 57, 851-867, https://doi.org/10.4319/lo.2012.57.3.0851, 2012.

Peng, Q., Xie, S.-P., Wang, D., Zheng, X.-T., and Zhang, H.: Coupled ocean-atmosphere dynamics of the 2017 extreme coastal El Niño, Nat. Commun., 10, 298, https://doi.org/10.1038/s41467018-08258-8, 2019.

Pennington, J. T., Mahoney, K. L., Kuwahara, V. S., Kolber, D. D., Calienes, R., and Chavez, F. P.: Primary production in the eastern tropical Pacific: A review, Prog. Oceanogr., 69, 285-317, https://doi.org/10.1016/j.pocean.2006.03.012, 2006.

Penven, P., Echevin, V., Pasapera, J., Colas, F., and Tam, J.: Average circulation, seasonal cycle, and mesoscale dynamics of the Peru Current System: A modeling approach, J. Geophys. Res.-Oceans, 110, C10021, https://doi.org/10.1029/2005JC002945, 2005.

Philander, S. G. H. and Yoon, J.-H.: Eastern Boundary Currents and Coastal Upwelling, J. Phys. Oceanogr., 12, 862-879, https://doi.org/10.1175/15200485(1982)012<0862:EBCACU>2.0.CO;2, 1982.

Pizarro, O., Shaffer, G., Dewitte, B., and Ramos, M.: Dynamics of seasonal and interannual variability of the PeruChile Undercurrent, Geophys. Res. Lett., 29, 22-1-22-4, https://doi.org/10.1029/2002GL014790, 2002.

Revsbech, N. P., Larsen, L. H., Gundersen, J., Dalsgaard, T., Ulloa, O., and Thamdrup, B.: Determination of ultralow oxygen concentrations in oxygen minimum zones by the STOX sensor, Limnol. Oceanogr.-Meth., 7, 371-381, https://doi.org/10.4319/lom.2009.7.371, 2009.

Romea, R. D. and Smith, R. L.: Further Evidence for Coastal Trapped Waves along the Peru Coast, J. Phys. Oceanogr., 13, 1341-1356, https://doi.org/10.1175/15200485(1983)013<1341:FEFCTW>2.0.CO;2, 1983.

Sakamoto, C. M., Johnson, K. S., and Coletti, L. J.: Improved algorithm for the computation of nitrate concentrations in seawater using an in situ ultraviolet spectrophotometer, Limnol. Oceanogr.-Meth., 7, 132-143, https://doi.org/10.4319/lom.2009.7.132, 2009.

Schunck, H., Lavik, G., Desai, D. K., Großkopf, T., Kalvelage, T., Löscher, C. R., Paulmier, A., Contreras, S., Siegel, H., Holtappels, M., Rosenstiel, P., Schilhabel, M. B., Graco, M., Schmitz, R. A., Kuypers, M. M. M., and LaRoche, J.: Giant Hydrogen Sulfide Plume in the Oxygen Minimum Zone 
off Peru Supports Chemolithoautotrophy, PLoS One, 8, 1-18, https://doi.org/10.1371/journal.pone.0068661, 2013.

Shaffer, G., Pizarro, O., Djurfeldt, L., Salinas, S., and Rutllant, J.: Circulation and Low-Frequency Variability near the Chilean Coast: Remotely Forced Fluctuations during the 1991-1992 El Niño, J. Phys. Oceanogr., 27, 217-235, https://doi.org/10.1175/15200485(1997)027<0217:CALFVN>2.0.CO;2, 1997.

Silva, N., Rojas, N., and Fedele, A.: Water masses in the Humboldt Current System: Properties, distribution, and the nitrate deficit as a chemical water mass tracer for Equatorial Subsurface Water off Chile, Deep Sea Res. Part II, 56, 1004-1020, https://doi.org/10.1016/j.dsr2.2008.12.013, 2009.

Sommer, S., Gier, J., Treude, T., Lomnitz, U., Dengler, M., Cardich, J., and Dale, A. W.: Depletion of oxygen, nitrate and nitrite in the Peruvian oxygen minimum zone cause an imbalance of benthic nitrogen fluxes, Deep Sea Res. Part I, 112, 113-122, https://doi.org/10.1016/j.dsr.2016.03.001, 2016.

Sommer, S., Dengler, M., and Shipboard Scientific Party: Benthic element cycling, fluxes and transport of nutrients and trace metals across the benthic boundary layer in the Peruvian oxygen minimum zone (SFB 754), Cruise No. 137, 6 May-29 May 2017, Callao (Peru) - Callao, METEOR-Berichte, https://doi.org/10.2312/cr_m137, 2019.

Strub, P. T., Mesias, J. M., Montecino, V., Rutllant, J., and Salinas, S.: Coastal ocean circulation off western South America, in: The Seas: The Global Coastal Ocean, vol. 11, edited by: Robinson, A. R. and Brink, K. H., pp. 273-313, John Wiley, New York, ISBN 0-471-11545-2, 1998.

Thomsen, S., Kanzow, T., Krahmann, G., Greatbatch, R. J., Dengler, M., and Lavik, G.: The formation of a subsurface anticyclonic eddy in the Peru-Chile Undercurrent and its impact on the near-coastal salinity, oxygen, and nutrient distributions, J. Geophys. Res.-Oceans, 121, 476-501, https://doi.org/10.1002/2015JC010878, 2016.

Thomsen, S., Karstensen, J., Kiko, R., Krahmann, G., Dengler, M., and Engel, A.: Remote and local drivers of oxygen and nitrate variability in the shallow oxygen minimum zone off Mauritania in June 2014, Biogeosciences, 16, 979-998, https://doi.org/10.5194/bg-16-979-2019, 2019.
Thyng, K. M., Greene, C. A., Hetland, R. D., Zimmerle, H. M., and DiMarco, S. F.: True Colors of Oceanography: Guidelines for Effective and Accurate Colormap Selection, Oceanography, 29, 9-13, https://doi.org/10.5670/oceanog.2016.66, 2016.

Ulloa, O., Canfield, D. E., DeLong, E. F., Letelier, R. M., and Stewart, F. J.: Microbial oceanography of anoxic oxygen minimum zones, P. Natl. Acad. Sci., 109, 15996-16003, https://doi.org/10.1073/pnas.1205009109, 2012.

Wang, D.-P.: Diffraction of Continental Shelf Waves by Irregular Alongshore Geometry, J. Phys. Oceanogr., 10, 1187-1199, https://doi.org/10.1175/15200485(1980)010<1187:DOCSWB>2.0.CO;2, 1980.

Wilkin, J. L. and Chapman, D. C.: Scattering of CoastalTrapped Waves by Irregularities in Coastline and Topography, J. Phys. Oceanogr., 20, 396-421, https://doi.org/10.1175/15200485(1990)020<0396:SOCTWB>2.0.CO;2, 1990.

Winkler, L. W.: Die Bestimmung des im Wasser gelösten Sauerstoffes, Ber. Dtsch. Chem. Ges., 21, 2843-2854, https://doi.org/10.1002/cber.188802102122, 1888.

Yoon, J.-H. and Philander, S. G. H.: The generation of coastal undercurrents, J. Oceanogr. Soc. Jpn., 38, 215-224, https://doi.org/10.1007/bf02111104, 1982.

$\mathrm{Yu}, \mathrm{X}$. and McPhaden, M. J.: Seasonal Variability in the Equatorial Pacific, J. Phys. Oceanogr., 29, 925-947 https://doi.org/10.1175/15200485(1999)029<0925:SVITEP>2.0.CO;2, 1999.

Zamora, L. M., Oschlies, A., Bange, H. W., Huebert, K. B., Craig, J. D., Kock, A., and Löscher, C. R.: Nitrous oxide dynamics in low oxygen regions of the Pacific: insights from the MEMENTO database, Biogeosciences, 9, 5007-5022, https://doi.org/10.5194/bg-9-5007-2012, 2012. 